\title{
Article \\ High Throughput Proteomic Exploration of Hypothermic Preservation Reveals Active Processes within the Cell Associated with Cold Ischemia Kinetic
}

\author{
Ophélie Pasini-Chabot ${ }^{1,2}$, Julia Vincent ${ }^{1,2}$, Sylvain Le Pape ${ }^{1,3}$, Maryne Lepoittevin ${ }^{1,3}$, Wassim Kaaki ${ }^{\text {, }}$ \\ Jean-Baptiste Woillard ${ }^{5,6} \mathbb{D}^{\mathbb{D}}$, Sebastien Giraud ${ }^{1,2,3,6}$, Nicolas Bourmeyster $2,7 \mathbb{D}$, Thierry Hauet ${ }^{1,2,3,6,8} \mathbb{D}$ and \\ Raphael Thuillier $1,2,3,6, *$ (D)
}

1 Inserm U1082, F-86000 Poitiers, France; ophelie-pasini@orange.fr (O.P.-C.); jujuvincent@hotmail.fr (J.V.); sylvain.le.pape@univ-poitiers.fr (S.L.P.); lepoittevin.maryne@gmail.com (M.L.); giraudseb@yahoo.fr (S.G.); thierry.hauet@univ-poitiers.fr (T.H.)

2 CHU Poitiers, Service de Biochimie, Pôle BIOSPHARM, F-86000 Poitiers, France; nicolas.bourmeyster@univ-poitiers.fr

3 Faculté de Médecine et de Pharmacie, Université de Poitiers, F-86000 Poitiers, France

4 Eurofins CEREP SA, F-86600 Celle-Lévescault, France; WassimKaaki@eurofins.com

5 Inserm, U1248 IPPRITT, F-87032 Limoges, France; jean-baptiste.woillard@unilim.fr

6 Fédération Hospitalo-Universitaire SUPORT, F-86000 Poitiers, France

check for updates

Citation: Pasini-Chabot, O.; Vincent, J.; Le Pape, S.; Lepoittevin, M.; Kaaki, W.; Woillard, J.-B.; Giraud, S.; Bourmeyster, N.; Hauet, T.; Thuillier, R. High Throughput Proteomic Exploration of Hypothermic

Preservation Reveals Active Processes within the Cell Associated with Cold Ischemia Kinetic. Int. J. Mol. Sci. 2021, 22, 2384. https://doi.org/10.3390/ ijms22052384

Academic Editor:

Joan Roselló-Catafau

Received: 18 December 2020

Accepted: 23 February 2021

Published: 27 February 2021

Publisher's Note: MDPI stays neutral with regard to jurisdictional claims in published maps and institutional affiliations.

Copyright: () 2021 by the authors. Licensee MDPI, Basel, Switzerland. This article is an open access article distributed under the terms and conditions of the Creative Commons Attribution (CC BY) license (https:// creativecommons.org/licenses/by/ $4.0 /)$.
7 UFR Sciences Fondamentales et Appliquées, Laboratoire STIM (ERL7268), Université de Poitiers, F-86000 Poitiers, France

8 IBiSA Plateforme 'MOPICT', Institut National de la Recherche Agronomique, Unité Expérimentale, Génétique, Expérimentations et Systèmes Innovants, Domaine Expérimental du Magneraud,

F-17700 Surgères, France

* Correspondence: Raphael.Thuillier@univ-poitiers.fr; Tel.: +33-5-49-44-44-44

\begin{abstract}
The demand for organs to be transplanted increases pressure on procurement centers, to the detriment of organ quality, increasing complications. New preservation protocols are urgently needed, requiring an in-depth understanding of ischemia-reperfusion mechanisms. We performed a proteomic analysis using LC-MS/MS-TOF data analyzed through R software and Cytoscape's ClueGO application, comparing the proteome of kidney endothelial cells, key cell type, subjected to 3 , $6,12,19$, and $24 \mathrm{~h}$ of cold ischemia and $6 \mathrm{~h}$ reperfusion. Critical pathways such as energy metabolism, cytoskeleton structure/transport system, and gene transcription/translation were modulated. Important time windows were revealed: a-during the first $3 \mathrm{~h}$, central proteins were upregulated within these pathways; $\mathrm{b}$ - the majority of these upregulations were maintained until $12 \mathrm{~h}$ cold ischemia time (CIT); c - after that time, the overall decrease in protein expression was observed; $d$-at reperfusion, proteins expressed in response to cold ischemia were all downregulated. This shows that cold ischemia is not a simple slowing down of metabolism, as deep changes take place within the proteome on major pathways. Time-sensitive expression of key protein reveals possible quality biomarkers as well as potential targets for new strategies to maintain or optimize organ quality.
\end{abstract}

Keywords: ischemia-reperfusion; organ preservation; cellular mechanism; proteomics; metabolism

\section{Introduction}

The rise of transplantation to the status of most adapted treatment for the end-stage renal disease has increased the demand for organs, surpassing the donation rate by several folds. This organ shortage led to the extension of donor criteria and definition of new donor categories: extended criteria donors (ECD) [1], which are donors aged over 60, or donors aged 50-59 with at least two of three additional risk factors including cerebrovascular accident as a cause of death, history of hypertension, and serum creatinine above $1.5 \mathrm{mg} / \mathrm{dL}$ prior to transplantation; deceased after circulatory death donors (DCD), in which the organ is subjected to a period of warm ischemia before procurement. Crucial in facing the organ 
shortage, these new organs are particularly sensitive to ischemia-reperfusion injury (IRI) [2], well defined as having a dramatic impact on short [3-5] and long term [6,7] outcome. Enabling these organs to better withstand IRI has thus become a priority in the transplant community, however, efforts to design new protocols for ECD organ preservation are impeded by the lack of mechanistic data on IRI.

Cold ischemia is generally described in simple terms as a stasis condition in which metabolism is slowed to approximately $10-14 \%$ of its original level, following the Van 't Hoff equation and the Arrhenius relation on the efficacy and speed of a chemical reaction, respectively $[8,9]$. However, a cell is significantly more complex than a test tube and is composed of structures particularly sensitive to cold ischemia [10] such as proteins [11,12] and phospholipid bilayer membranes [13]. Moreover, temperature also influences bonds central to cellular processes, such as the hydrogen bond [14,15] and the hydrophobic effect [16]. In this light, cold ischemia likely induces complex cellular rearrangements.

We and others have actively pursued the definition of IRI mechanisms for some time $[17,18]$. A recent development in high throughput technologies and system biology $[19,20]$ opens the possibility of an "open-ended" approach in which a lesion can be studied with as broad a viewpoint as possible. Herein, we attempt such an approach to decipher the cellular consequences of cold ischemia using proteomics. An in vitro model is used, with endothelial cells subjected to hypothermia and anoxia in conditions mimicking the stresses of organ preservation: rinsing with cold preservation solution and static storage for up to $24 \mathrm{~h}$. While limited in scope, this model permits a reduction in the number of variables, which is not the case in a multi-cell type organ.

\section{Results}

\subsection{Data Segregation}

The analysis procedure is schematized in Figure 1, 174 human proteins with an MW above $30 \mathrm{kDa}$ were analyzed. 


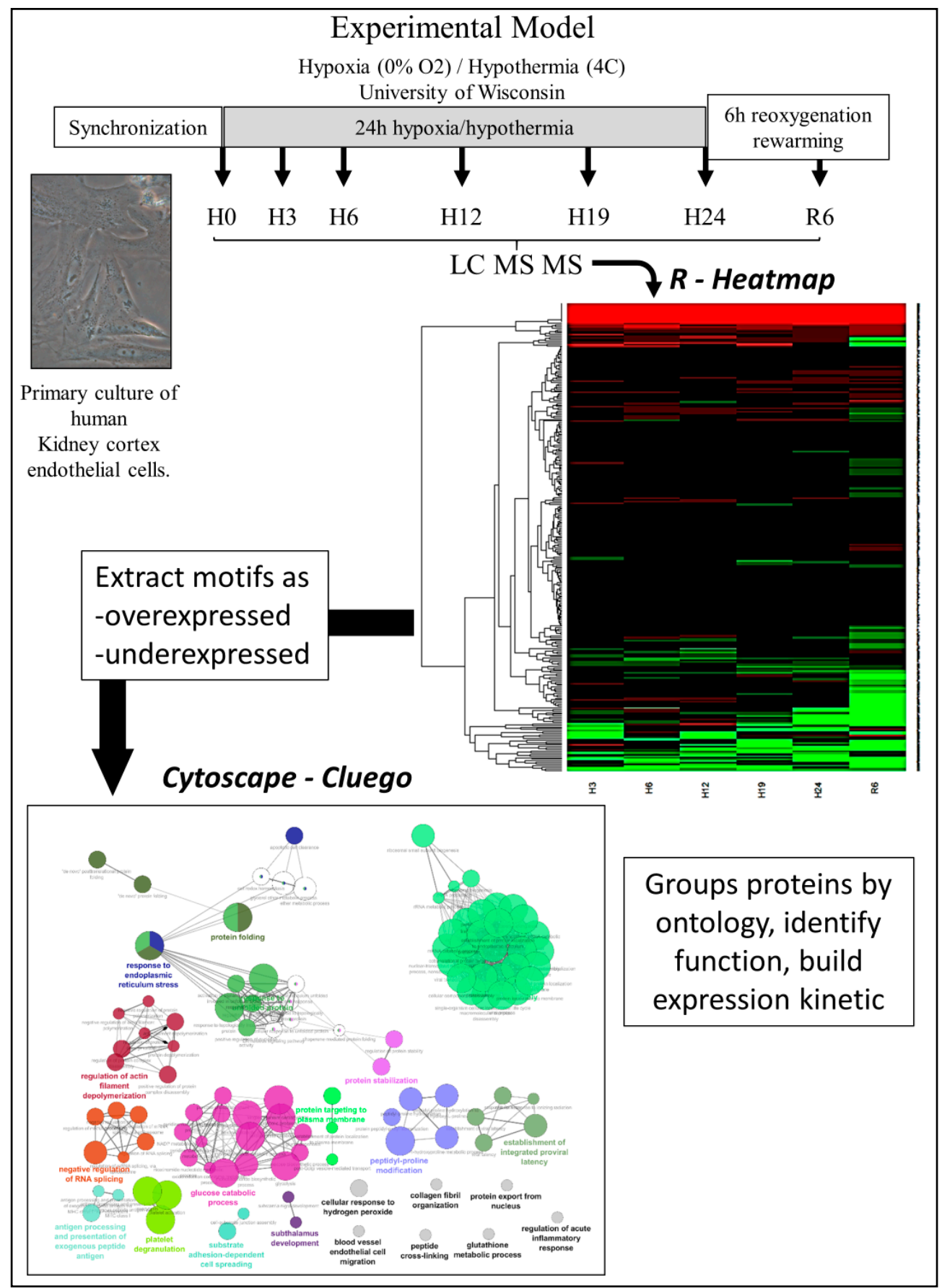

Figure 1. Experimental model and analysis strategy. Primary human renal glomerular endothelial cells (HRGEC) were synchronized and were subjected to cold-ischemia like conditions: incubation in a hermetic chamber at $4{ }^{\circ} \mathrm{C}$ containing a hypoxic atmosphere: $0 \% \mathrm{O}_{2}, 5 \% \mathrm{CO}_{2}$, and $95 \% \mathrm{~N}_{2}$ for up to $24 \mathrm{~h}$ (Hypothermic/Hypoxic period, $\mathrm{H}$ ), in University of Wisconsin solution, then washed and incubated in regular culture conditions (Reperfusion period, R). At each time point, cell monolayers were collected for analysis. After LC-MS/MS analysis, a heatmap was generated to distinguish protein motifs by their variation, and each group was analyzed using Cytoscape's ClueGO to identify their ontology and network associations.

A heatmap was generated (Figure 2) and proteins grouped into 3 categories: proteins unchanged by the protocol (in white), proteins significantly altered by the protocol at any time point (determined by Mann-Whitney U test), either upregulated (in blue) or downregulated (in red). 


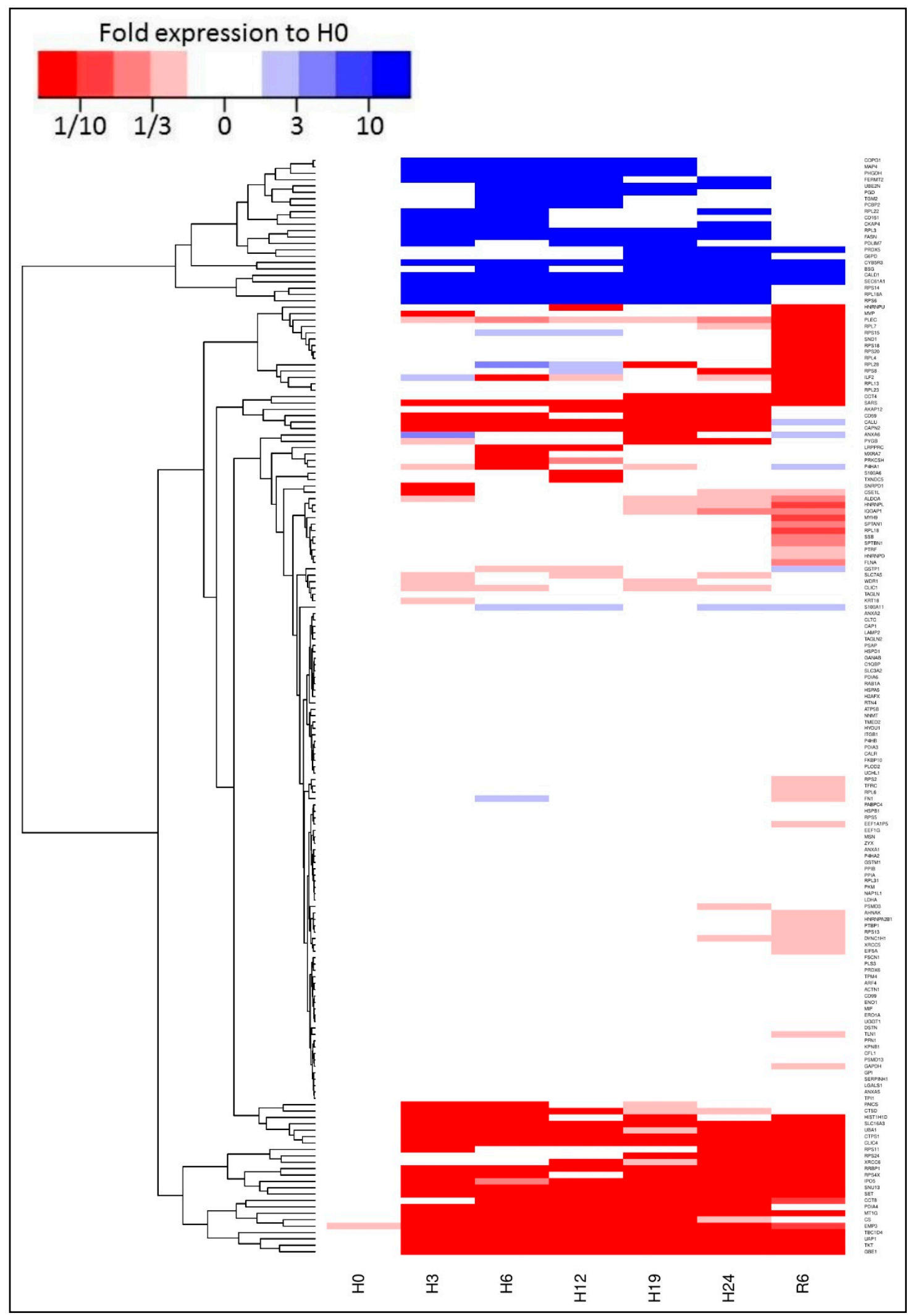

Figure 2. Proteome heatmap. A heatmap was generated using the R software, highlighting three groups of protein motifs using as criteria a variation of expression of more than 2 folds between the conditions: proteins unchanged by the protocol (white), protein increasing in expression (Blue), and protein decreasing in expression (Red). 


\subsection{Unchanged Proteins}

While the protocol represented drastic alterations of the cell's environment, a number of motifs remained unaltered (Table 1, Figure 3), belonging to families involved in protein production and folding (Peptidyl-proline modification, Peptidyl-asparagine modification, Protein folding, Protein stabilization) and in protein transport (Microtubule-based transport, Protein export from the nucleus). Another represented pathway was glycolysis, the key to energy metabolism.

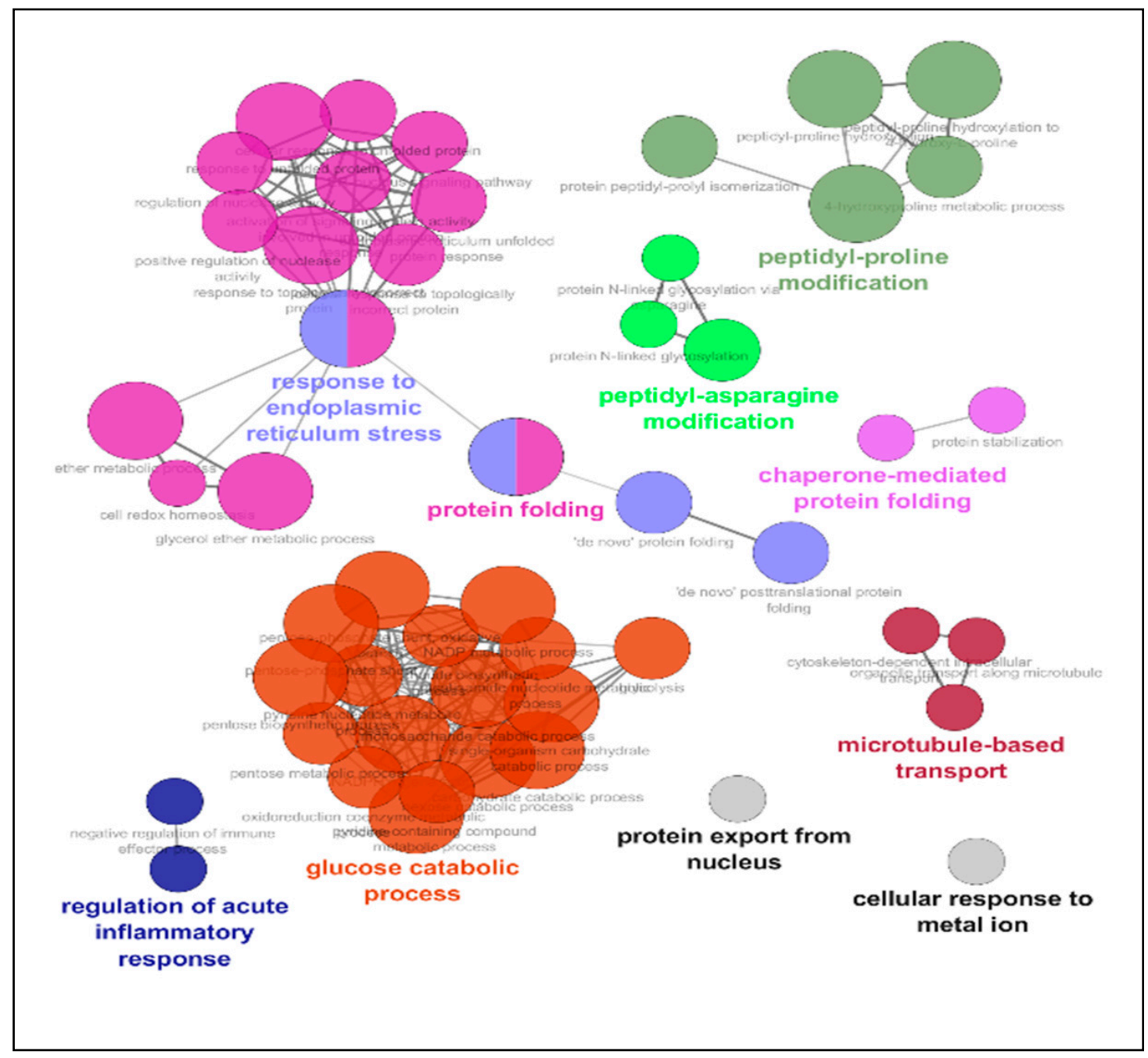

Figure 3. ClueGO Network Representation of unaltered motifs during the full protocol. The list of protein motifs unaffected by the protocol were analyzed in Cytoscape's ClueGO to identify their ontology and network associations. Results are illustrated as a functionally grouped network of terms/pathways. The most significant term of a group is considered to be the leading terms and is highlighted (bolded name). Disc size represents the number of motifs identified in the specified ontology (small: 3-6; medium: 7-9; large: 10 and more).

\subsection{Proteins Affected by Anoxic Hypothermia}

\subsection{1. $\mathrm{H} 0-\mathrm{H} 3$}

In the first $3 \mathrm{~h}$ of the protocol, ontology analysis (Table 2), we observed de novo expression of several proteins, belonging to cytoskeletal structure and cellular adhesion. The majority of changes were detected in the transcription/translation machinery, with ribosomal proteins and RNA and peptide transports. The ionic balance was also concerned by new protein productions. In terms of downregulated motifs, both the energy metabolism and nucleotide biosynthesis were affected, as well as cell surface adhesion and RedOx 
regulation. Network analysis (Figure 4) confirmed the increased expression of protein motifs involved in RNA maturation (translation and ribosome biogenesis), as well as the impact on the energy metabolism, with the reconfiguration of the pentose biosynthetic process, and decrease of the NADPH metabolic process.

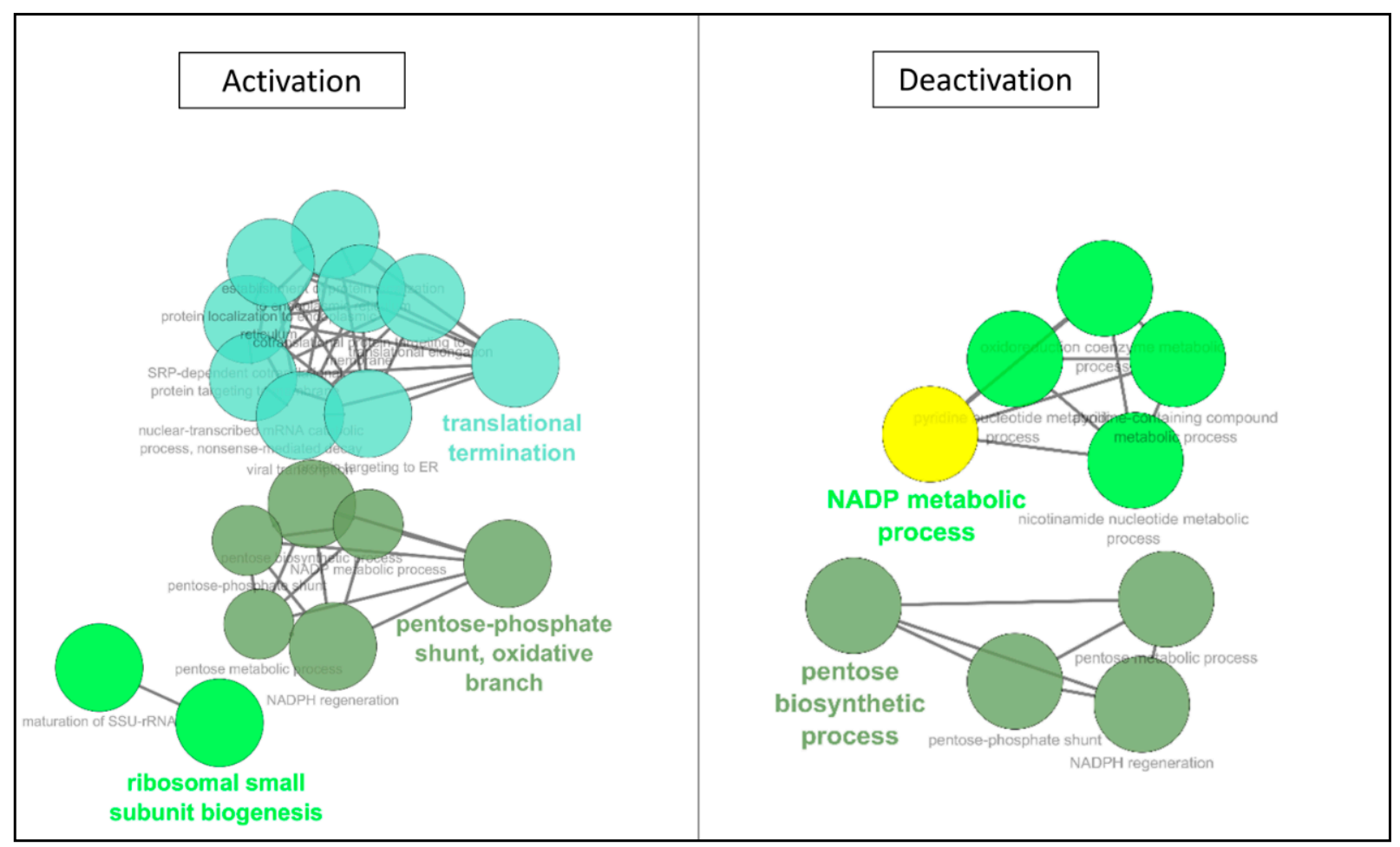

Figure 4. ClueGO Network Representation of Affected motifs between 0 and $3 \mathrm{~h}$ of hypothermic hypoxia. The list of protein motifs unaffected by the protocol were analyzed in Cytoscape's ClueGO to identify their ontology and network associations. Results are illustrated as a functionally grouped network of terms/pathways. The most significant term of a group is considered to be the leading terms and is highlighted (bolded name). Disc size represents the number of motifs identified in the specified ontology (small: 3-6; medium: 7-9; large: 10 and more).

\subsubsection{H3-H6}

Prolonging hypothermic anoxia, ontology analysis (Table 3) showed that ionic balance regulation was also represented in the de novo expression. Whereas in the "interaction with the environment" family, the CD151 antigen produced during H0-H3 was downregulated. Interestingly, the ontologic families "Transcription/Translation Regulation" and "Cytoskeleton" were represented in both downregulated and upregulated motifs categories. Network analysis (Figure 5) demonstrated that reprogramming of RNA maturation and energy metabolism was ongoing, as well as a negative impact on cytoskeletal features. 


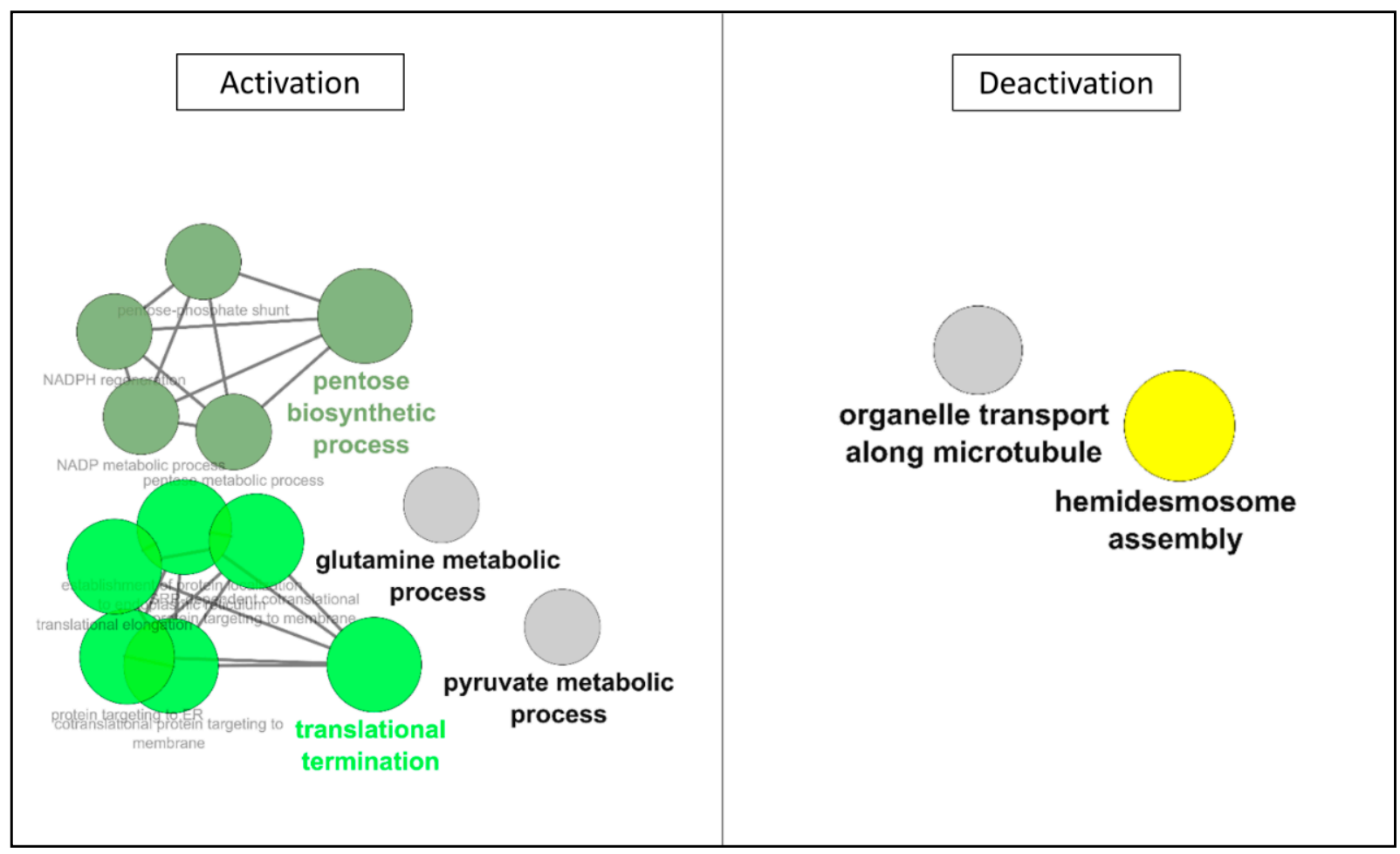

Figure 5. ClueGO Network Representation of Affected motifs between 3 and 6 h of hypothermic hypoxia. The list of protein motifs unaffected by the protocol were analyzed in Cytoscape's ClueGO to identify their ontology and network associations. Results are illustrated as a functionally grouped network of terms/pathways. The most significant term of a group is considered to be the leading terms and is highlighted (bolded name). Disc size represents the number of motifs identified in the specified ontology (small: 3-6; medium: 7-9; large: 10 and more).

\subsection{3. $\mathrm{H} 6-\mathrm{H} 12$}

Reaching the half-time point (Table 4), ontology analysis showed three families still represented in the de novo motif synthesis section: cytoskeleton, the interaction between the cell and its environment which is closely linked to the cytoskeleton, and Transcription/Translation Regulation. The downregulated motifs remain limited, highlighting intracellular priority reshuffling with families such as transport and cell adhesion. The number of motifs were insufficient to conduct network analysis with ClueGO.

\subsection{4. $\mathrm{H} 12-\mathrm{H} 19$}

In this time window, the exploration of ontologies (Table 5) showed seemed to be a shift in the cell's behavior. While there remained a few upregulations, with similar families as previous time windows such as intracellular transport, Transcription/Translation Regulation, and interaction with the environment, here energy metabolism was also concerned. The main alterations are however observed in the downregulated section; with a large number of motifs belonging to families which were upregulated in the first half of the procedure: cytoskeleton, interaction with the environment, intracellular transport, and importantly Transcription/Translation Regulation. Ionic imbalance, Energy metabolism, and RedOx regulation were also implicated. Network analysis (Figure 6) confirmed that activations appeared reduced, limited to cytoskeleton-related networks, whereas deactivations were more widespread, with networks previously upregulated during the first $12 \mathrm{~h}$. 


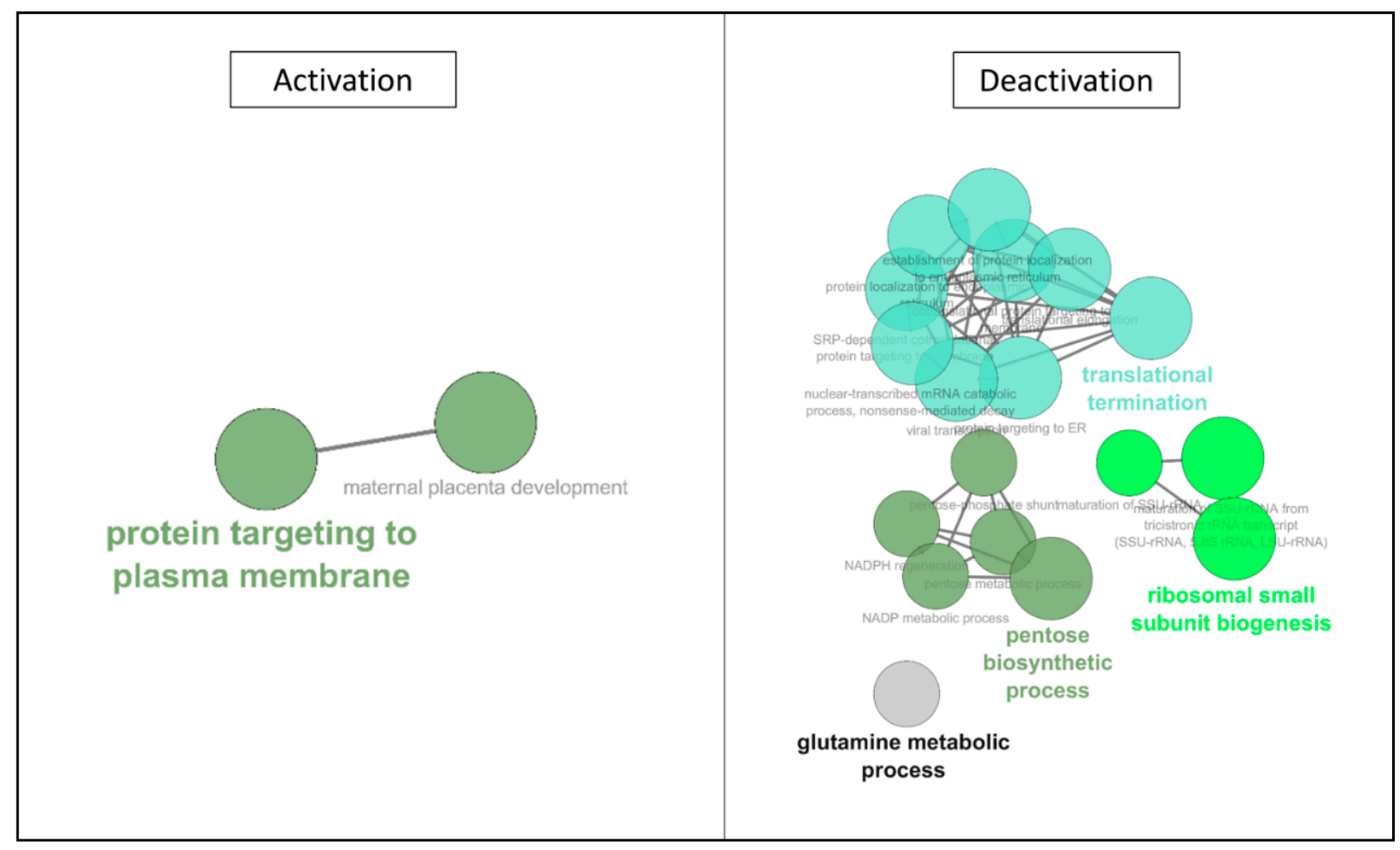

Figure 6. ClueGO Network Representation of Affected motifs between 12 and $19 \mathrm{~h}$ of hypothermic hypoxia. The list of protein motifs unaffected by the protocol were analyzed in Cytoscape's ClueGO to identify their ontology and network associations. Results are illustrated as a functionally grouped network of terms/pathways. The most significant term of a group is considered to be the leading terms and is highlighted (bolded name). Disc size represents the number of motifs identified in the specified ontology (small: 3-6; medium: 7-9; large: 10 and more).

\subsection{5. $\mathrm{H} 19-\mathrm{H} 24$}

Reaching the end of the preservation time (Table 6), we observed the same phenomenon, with only a few upregulated motifs and a majority of downregulated proteins with the major families: Cytoskeleton and Transcription/Translation Regulation as well as energy metabolism and the proteasome. The number of motifs were insufficient to draw a network with ClueGO.

\subsection{Protein Alteration at Rewarming/Reoxygenation}

After $6 \mathrm{~h}$ of being cultured back in normal conditions (Table 7), we observed an important downregulation of a large number of motifs while no new proteins are detected. The majority of motifs being downregulated belong to cytoskeleton and Transcription/Translation Regulation families, and other represented families are energy metabolism, interaction with the environment, and ionic balance regulation. Network analysis (Figure 7) confirmed this, notably showing activation of previously deactivated pathways (such as NADP and pyruvate processes), and particularly demonstrating deactivation of pathways specifically induced by ischemia, specifically RNA translation reprogramming. 


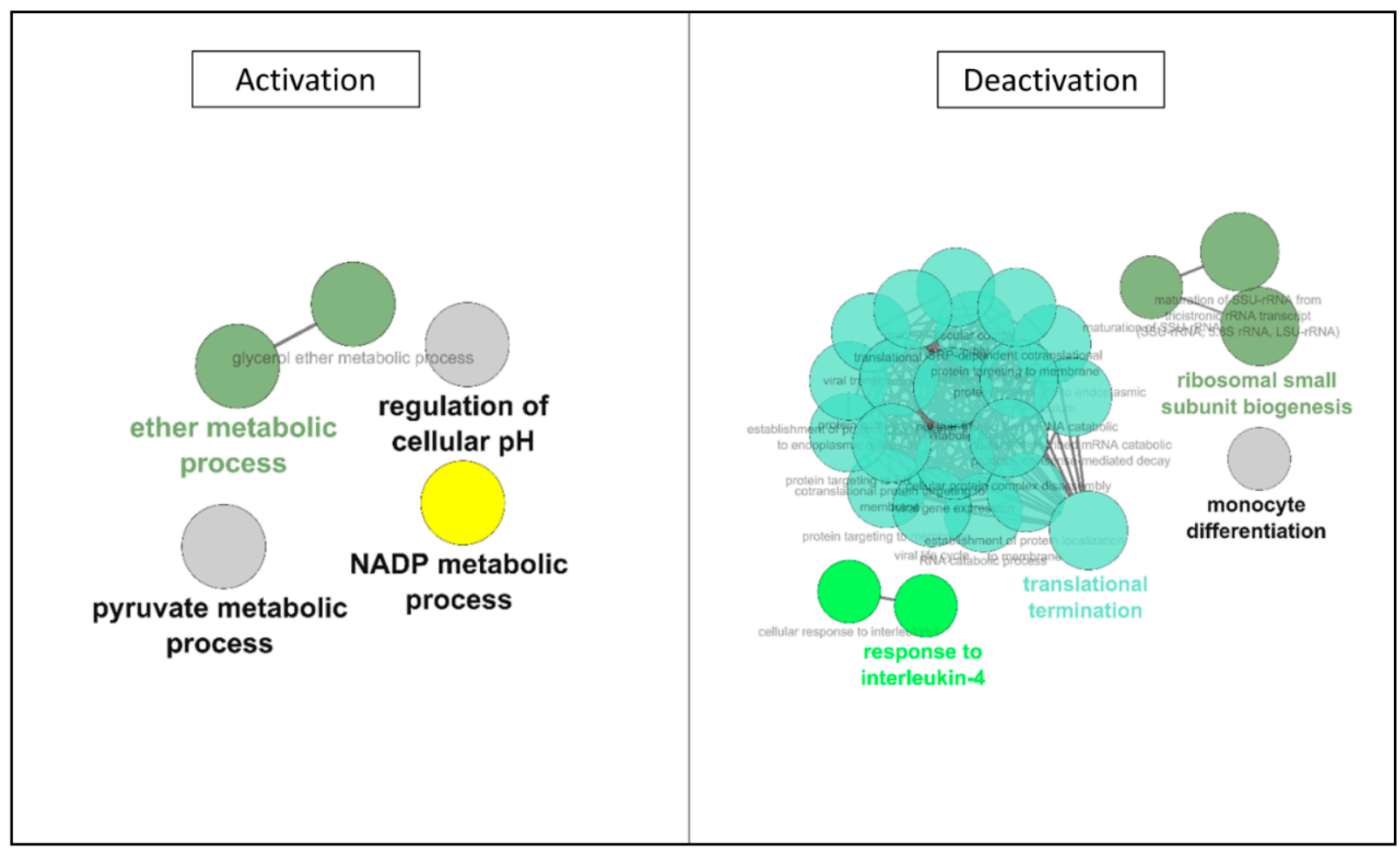

Figure 7. ClueGO Network Representation of Affected motifs after 6 h reoxygenation/rewarming. The list of protein motifs unaffected by the protocol were analyzed in Cytoscape's ClueGO to identify their ontology and network associations. Results are illustrated as a functionally grouped network of terms/pathways. The most significant term of a group is considered to be the leading terms and is highlighted (bolded name). Disc size represents the number of motifs identified in the specified ontology (small: 3-6; medium: 7-9; large: 10 and more).

\subsection{Kinetic of the Protein Expression Alteration during the Procedure}

To obtain a global view of the alterations over time, we represented the average change in expression for each ontology in two different fashion (Figure 8): either the change observed in each time period independently (left panel) or the cumulated change (right panel). We performed this analysis for each of the four most affected ontologies: Cytoskeleton, Transcription/Translation Regulation, Ionic Balance Regulation, Energy metabolism.

Two patterns were observable:

1-In response to the drastic changes in conditions, important de novo expression was taking place within the cell $(\mathrm{H} 0-\mathrm{H} 3)$. This increase was not found afterward, however, the level was maintained for a certain duration. After a certain time period, protein expression collapsed. Interestingly, all three ontologies showing this pattern did not show the same kinetic. The first to start decreasing was the Transcription/Translation Regulation: as soon as $3 \mathrm{~h}$ were passed, the expression level tends to decrease, a trend which worsened over time. The ionic balance regulation maintained its higher expression levels until $12 \mathrm{~h}$, then collapsed. The Cytoskeleton was the last to collapse, starting at H19. This pattern was also characterized by a further lowering of protein expression levels at reoxygenation.

2-In response to hypothermia and anoxia, the expression level of proteins belonging to the energy metabolism ontology collapsed; however, it was soon followed by de novo expression of protein motifs, which remained higher until $12 \mathrm{~h}$, upon which expression collapsed again. At reoxygenation, a major increase in protein expression was recorded. 


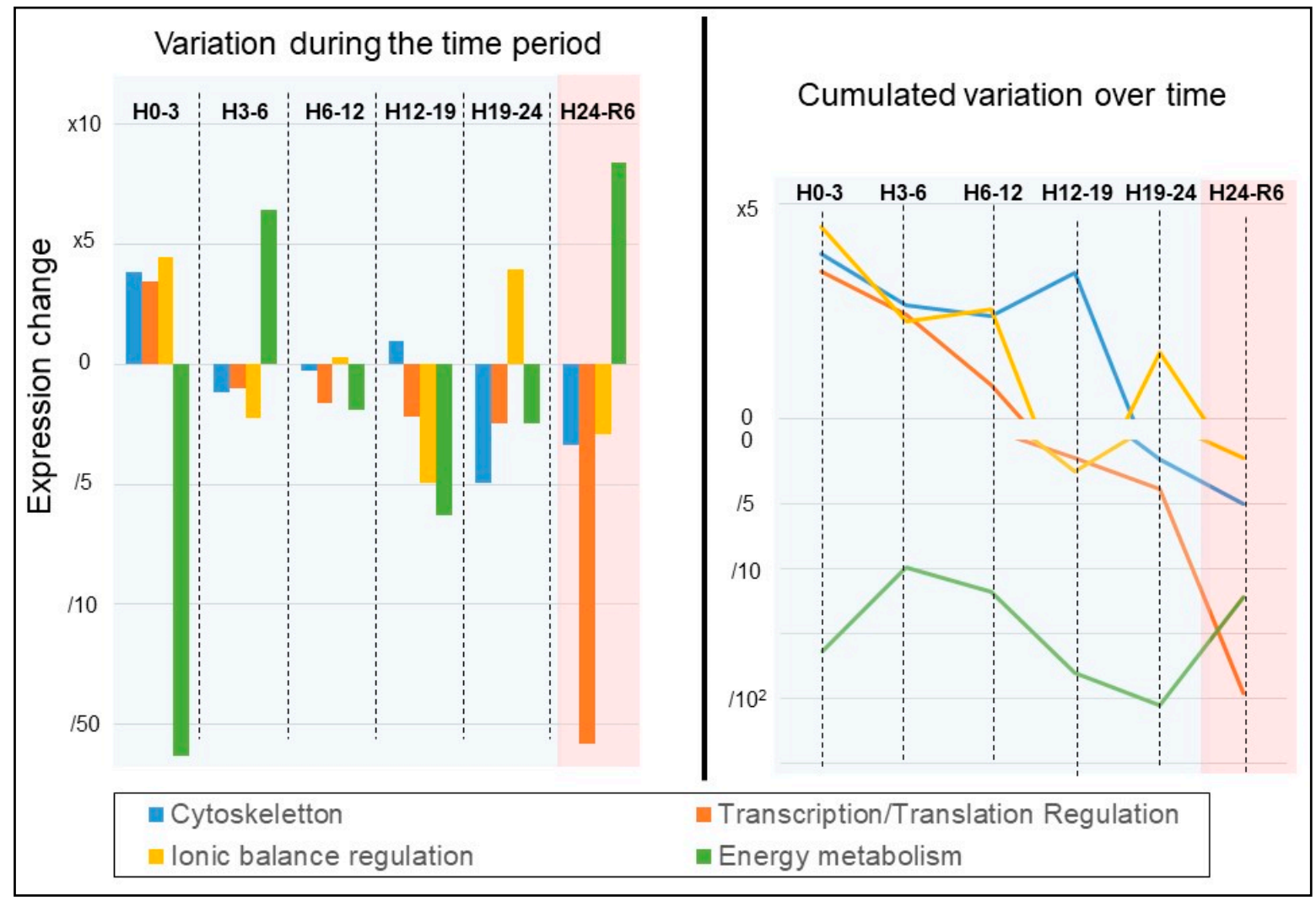

Figure 8. Kinetics of protein expression during the procedure, by ontology. We averaged the expression change for the proteins belonging to the most represented ontologies: Cytoskeleton, Transcription/Translation Regulation, Ionic Balance Regulation, Energy metabolism. Left Panel: average change reported for each time period independently. Right Panel: cumulated change in expression over time. $(\mathrm{N}=3, n=3)$.

\subsection{Remarkable Protein Motifs Affected by Ischemia-Reperfusion}

Within the modulated motifs, across all the time point, several are prominent:

\subsubsection{Cytoskeleton Ontology}

Plectin: an intermediate filament-associated protein, acting as a cytoskeletal crosslinker and signaling scaffold, was downregulated between 6 and $12 \mathrm{~h}$.

S100A6: a member of a superfamily of EF-hand $\mathrm{Ca}^{2+}$-binding proteins, was upregulated between 3 and $6 \mathrm{~h}$, remained stable until $19 \mathrm{~h}$ of preservation conditions, then further increased, one of the very few motifs doing so at that time.

\subsubsection{Transcription/Translation Ontology}

A detailed observation of the impacted motifs shows that the majority coding for ribosomal proteins, accompanied by transcription factors, RNA and protein adaptor/elongation proteins, and even histones. Among the later:

- Interleukin-2 enhancer-binding factor 2 (ILF2), is one of the proteins being overexpressed at the start, with the maintenance of this expression level until $12 \mathrm{~h}$, upon which it is further overexpressed whereas the majority of motifs in this ontologic family are depressed. Only after $19 \mathrm{~h}$ do we observe the downregulation of ILF2.

- Eukaryotic translation elongation factor 1 gamma (EEF1G) is a component of the translation apparatus, the eEF1 complex. We observe that its expression is constant at first then overexpressed between 6 and $12 \mathrm{~h}$, before being downregulated constantly until the end of the procedure. 
- $\quad$ H2A histone family member X (H2AFX, also known as H2AX), an important member of the DNA damage detection and repair apparatus, is one of the only two motifs detected to be overexpressed between 19 and $24 \mathrm{~h}$ of preservation.

\subsubsection{Energy Metabolism Ontology}

Of the modulated motifs, we note:

- $\quad$ Transketolase (TKT), a key enzyme of the pentose phosphate pathway, was upregulated between 3 and $6 \mathrm{~h}$ and downregulated after $12 \mathrm{~h}$.

- $\quad$ TBC1D4, a Rab GTPase-activating protein, was upregulated between 3 and $6 \mathrm{~h}$ and downregulated after $12 \mathrm{~h}$.

- Prosaposin (PSAP), a precursor to saponins, was overexpressed between 12 and $19 \mathrm{~h}$.

\subsubsection{Ionic Balance Ontology}

One of the most affected ontology family with several markers of interest:

- Neuroblast differentiation-associated protein AHNAK, also known as desmoyokin, showed a maintained expression until $12 \mathrm{~h}$, after which it is recorded as decreased both between 12 and $19 \mathrm{~h}$ as well as between 19 and $24 \mathrm{~h}$.

- Annexin A6 (ANXA6), a member of the annexins family of $\mathrm{Ca}^{2+}$ dependent phospholipidbinding proteins, was upregulated as soon as the cell was subjected to organ preservation conditions, likely related to $\mathrm{pH}$ alterations, and remained elevated until $12 \mathrm{~h}$ of preservation.

Table 1. Proteins which expression was maintained throughout the course of hypoxia/hypothermia and reoxygenation.

\begin{tabular}{|c|c|c|}
\hline Protein ID & Protein Name & Protein Function \\
\hline \multicolumn{3}{|c|}{ Peptidyl-proline modification } \\
\hline FKBP10 & peptidyl-prolyl cis-trans isomerase FKBP10 & Accelerates the folding of proteins during synthesis. \\
\hline P4HA1 & Prolyl 4-hydroxylase subunit alpha-1 & $\begin{array}{l}\text { Quaternary maturation: Catalyzes the post-translational formation of } \\
\text { 4-hydroxyproline in -Xaa-Pro-Gly- sequences in collagens and other } \\
\text { proteins. }\end{array}$ \\
\hline P4HA2 & prolyl 4-hydroxylase subunit alpha-2 & $\begin{array}{l}\text { Quaternary maturation: Catalyzes the post-translational formation of } \\
\text { 4-hydroxyproline in -Xaa-Pro-Gly- sequences in collagens and other } \\
\text { proteins. }\end{array}$ \\
\hline $\mathrm{P} 4 \mathrm{HB}$ & protein disulfide-isomerase & Catalyzes the formation, breakage, and rearrangement of disulfide bonds. \\
\hline PPIA & peptidyl-prolyl cis-trans isomerase A & Accelerates the folding of proteins during synthesis. \\
\hline PPIB & Peptidyl-prolyl cis-trans isomerase B & Accelerates the folding of proteins during synthesis. \\
\hline \multicolumn{3}{|c|}{ Peptidyl-asparagine modification } \\
\hline CALR & Calreticulin & $\begin{array}{l}\text { Calcium-binding chaperone that promotes folding, oligomeric assembly, } \\
\text { and quality control in the endoplasmic reticulum (ER). }\end{array}$ \\
\hline GANAB & neutral alpha-glucosidase $A B$ & Catalyzes the maturation of oligosaccharide precursors on proteins. \\
\hline PDIA3 & protein disulfide-isomerase $\mathrm{A} 3$ & Catalyzes the rearrangement of -S-S- bonds in proteins. \\
\hline UAP1 & UDP-N-acetylhexosamine pyrophosphorylase & $\begin{array}{l}\text { Converts UTP and GlcNAc-1-P into UDP-GlcNAc, and UTP and } \\
\text { GalNAc-1-P into UDP-GalNAc. }\end{array}$ \\
\hline UGGT1 & UDP-glucose: glycoprotein glucosyltransferase 1 & $\begin{array}{l}\text { Provides quality control for glycoprotein folding in the endoplasmic } \\
\text { reticulum. }\end{array}$ \\
\hline \multicolumn{3}{|c|}{ Protein folding } \\
\hline CALR & Calreticulin & $\begin{array}{l}\text { Calcium-binding chaperone that promotes folding, oligomeric assembly, } \\
\text { and quality control in the endoplasmic reticulum (ER). }\end{array}$ \\
\hline CCT4 & T-complex protein 1 subunit delta & Molecular chaperone; assists the folding of proteins upon ATP hydrolysis. \\
\hline ССТ8 & T-complex protein 1 subunit theta & Molecular chaperone; assists the folding of proteins upon ATP hydrolysis. \\
\hline ERO1A & ERO1-like protein alpha & $\begin{array}{l}\text { Oxidoreductase is involved in disulfide bond formation in the } \\
\text { endoplasmic reticulum. }\end{array}$ \\
\hline FKBP10 & peptidyl-prolyl cis-trans isomerase FKBP10 & Accelerates the folding of proteins during synthesis. \\
\hline GANAB & neutral alpha-glucosidase $\mathrm{AB}$ & Catalyzes the maturation of oligosaccharide precursors on proteins. \\
\hline
\end{tabular}


Table 1. Cont.

\begin{tabular}{|c|c|c|}
\hline Protein ID & Protein Name & $\begin{array}{l}\text { Protein Function } \\
\end{array}$ \\
\hline HSPA5 & $78 \mathrm{kDa}$ glucose-regulated protein & $\begin{array}{l}\text { Involved in the correct folding of proteins and degradation of misfolded } \\
\text { proteins }\end{array}$ \\
\hline HSPD1 & $60 \mathrm{kDa}$ heat shock protein, mitochondrial & $\begin{array}{l}\text { Chaperonin is implicated in mitochondrial protein import and } \\
\text { macromolecular assembly. }\end{array}$ \\
\hline $\mathrm{P} 4 \mathrm{HB}$ & protein disulfide-isomerase & Catalyzes the formation, breakage, and rearrangement of disulfide bonds. \\
\hline PDIA3 & protein disulfide-isomerase $\mathrm{A} 3$ & Catalyzes the rearrangement of -S-S- bonds in proteins. \\
\hline PDIA6 & protein disulfide-isomerase A6 & Chaperone that inhibits aggregation of misfolded proteins. \\
\hline PPIA & peptidyl-prolyl cis-trans isomerase A & Accelerates the folding of proteins during synthesis. \\
\hline PPIB & Peptidyl-prolyl cis-trans isomerase B & Accelerates the folding of proteins during synthesis. \\
\hline TXNDC5 & Thioredoxin domain-containing protein 5 & Possesses thioredoxin activity \\
\hline UGGT1 & UDP-glucose: glycoprotein glucosyltransferase 1 & $\begin{array}{l}\text { Provides quality control for glycoprotein folding in the endoplasmic } \\
\text { reticulum. }\end{array}$ \\
\hline TLN1 & Talin-1 & $\begin{array}{c}\text { Probably involved in connections of major cytoskeletal structures to the } \\
\text { plasma membrane. }\end{array}$ \\
\hline HYOU1 & Hypoxia up-regulated protein 1 & Plays a role as a molecular chaperone and participates in protein folding. \\
\hline SERPINH1 & serpin $\mathrm{H} 1$ & Involved as a chaperone in the biosynthetic pathway of collagen. \\
\hline \multicolumn{3}{|c|}{ Cellular response to metal ion } \\
\hline CALR & Calreticulin & $\begin{array}{l}\text { Calcium-binding chaperone that promotes folding, oligomeric assembly, } \\
\text { and quality control in the endoplasmic reticulum (ER). }\end{array}$ \\
\hline CLIC4 & Chloride intracellular channel protein 4 & $\begin{array}{l}\text { Can insert into membranes and form poorly selective ion channels that } \\
\text { may also transport chloride ions. }\end{array}$ \\
\hline FASN & Fatty acid synthase & $\begin{array}{l}\text { Catalyzes the formation of long-chain fatty acids from acetyl-CoA, } \\
\text { malonyl-CoA, and NADPH. }\end{array}$ \\
\hline MT1G & Metallothionein-1G & Negative regulation of growth \\
\hline \multicolumn{3}{|c|}{ Glucose catabolic process } \\
\hline ENO1 & Alpha-enolase & $\begin{array}{l}\text { The multifunctional enzyme, as well as its role in glycolysis, plays a part } \\
\text { in various processes such as growth control, hypoxia tolerance, and } \\
\text { allergic responses. }\end{array}$ \\
\hline G6PD & Glucose-6-phosphate 1-dehydrogenase & $\begin{array}{l}\text { Catalyzes the rate-limiting step of the oxidative pentose-phosphate } \\
\text { pathway. }\end{array}$ \\
\hline GPI & Glucose-6-phosphate isomerase & Glycolytic enzyme. \\
\hline LDHA & L-lactate dehydrogenase A chain & $\begin{array}{l}\text { Involved in step } 1 \text { of the subpathway that synthesizes (S)-lactate from } \\
\text { pyruvate }\end{array}$ \\
\hline PGD & $\begin{array}{l}\text { 6-phosphogluconate dehydrogenase, } \\
\text { decarboxylating }\end{array}$ & $\begin{array}{l}\text { Catalyzes the oxidative decarboxylation of 6-phosphogluconate to } \\
\text { ribulose 5-phosphate and CO2, with concomitant reduction of NADP to } \\
\text { NADPH }\end{array}$ \\
\hline PHGDH & D-3-phosphoglycerate dehydrogenase & $\begin{array}{l}\text { Catalyzes the reversible oxidation of 3-phospho-D-glycerate to } \\
\text { 3-phosphonooxypyruvate, the first step of the phosphorylated L-serine } \\
\text { biosynthesis pathway. }\end{array}$ \\
\hline PKM & Pyruvate kinase PKM & $\begin{array}{l}\text { The glycolytic enzyme that catalyzes the transfer of a phosphoryl group } \\
\text { from phosphoenolpyruvate (PEP) to ADP, generating ATP. }\end{array}$ \\
\hline TPI1 & Triosephosphate isomerase & $\begin{array}{c}\text { Involved in the pathway gluconeogenesis, which is part of Carbohydrate } \\
\text { biosynthesis }\end{array}$ \\
\hline PRDX5 & Peroxiredoxin-5, mitochondrial & NADP metabolic process \\
\hline \multicolumn{3}{|c|}{ Protein stabilization } \\
\hline CALR & Calreticulin & $\begin{array}{l}\text { Calcium-binding chaperone that promotes folding, oligomeric assembly, } \\
\text { and quality control in the endoplasmic reticulum (ER). }\end{array}$ \\
\hline HSPD1 & $60 \mathrm{kDa}$ heat shock protein, mitochondrial & $\begin{array}{l}\text { Chaperonin is implicated in mitochondrial protein import and } \\
\text { macromolecular assembly. }\end{array}$ \\
\hline LAMP2 & Lysosome-associated membrane glycoprotein 2 & Plays an important role in chaperone-mediated autophagy \\
\hline PPIB & Peptidyl-prolyl cis-trans isomerase B & Accelerates the folding of proteins during synthesis. \\
\hline ERO1A & ERO1-like protein alpha & $\begin{array}{c}\text { Oxidoreductase is involved in disulfide bond formation in the } \\
\text { endoplasmic reticulum. }\end{array}$ \\
\hline
\end{tabular}


Table 1. Cont.

\begin{tabular}{|c|c|c|}
\hline Protein ID & Protein Name & Protein Function \\
\hline \multicolumn{3}{|c|}{ Microtubule-based transport } \\
\hline COPG1 & Coatomer subunit gamma-1 & $\begin{array}{l}\text { Mediates biosynthetic protein transport from the ER, via the Golgi up to } \\
\text { the trans-Golgi network. }\end{array}$ \\
\hline LRPPRC & $\begin{array}{l}\text { Leucine-rich PPR motif-containing protein, } \\
\text { mitochondrial }\end{array}$ & May play a role in RNA metabolism in both nuclei and mitochondria. \\
\hline RAB1A & Ras-related protein Rab-1A & $\begin{array}{l}\text { The small GTPases Rab are key regulators of intracellular membrane } \\
\text { trafficking, from the formation of transport vesicles to their fusion with } \\
\text { membranes. }\end{array}$ \\
\hline UCHL1 & Ubiquitin C-Terminal Hydrolase L1 & $\begin{array}{l}\text { This enzyme is a thiol protease that hydrolyzes a peptide bond at the } \\
\text { C-terminal glycine of ubiquitin. }\end{array}$ \\
\hline \multicolumn{3}{|c|}{ Protein export from the nucleus } \\
\hline CALR & Calreticulin & $\begin{array}{c}\text { Calcium-binding chaperone that promotes folding, oligomeric assembly, } \\
\text { and quality control in the endoplasmic reticulum (ER). }\end{array}$ \\
\hline CSE1L & Exportin-2 & Export receptor for importin-alpha. \\
\hline EIF5A & Eukaryotic translation initiation factor $5 \mathrm{~A}-1$ & mRNA-binding protein involved in translation elongation. \\
\hline \multicolumn{3}{|c|}{ Regulation of acute inflammatory response } \\
\hline ANXA1 & Annexin A1 & $\begin{array}{l}\text { Plays important roles in the innate immune response as an effector of } \\
\text { glucocorticoid-mediated responses and regulator of the inflammatory } \\
\text { process. }\end{array}$ \\
\hline C1QBP & $\begin{array}{l}\text { Complement component } 1 \mathrm{Q} \\
\text { subcomponent-binding protein, mitochondrial }\end{array}$ & $\begin{array}{c}\text { Involved in inflammation and infection processes, ribosome biogenesis, } \\
\text { regulation of apoptosis, transcriptional regulation, and pre-mRNA } \\
\text { splicing }\end{array}$ \\
\hline CD59 & CD59 glycoprotein & $\begin{array}{l}\text { Potent inhibitor of the complement membrane attack complex (MAC) } \\
\text { action. }\end{array}$ \\
\hline РCBP2 & Poly(rC)-binding protein 2 & $\begin{array}{l}\text { Single-stranded nucleic acid-binding protein that binds preferentially to } \\
\text { oligo } \mathrm{dC} .\end{array}$ \\
\hline
\end{tabular}

Table 2. Proteins which expression was altered between $\mathrm{HO}$ and $\mathrm{H} 3$.

\begin{tabular}{|c|c|c|}
\hline A: UPREGULATED & & \\
\hline Acronym & Name & Function \\
\hline \multicolumn{3}{|c|}{ Cytoskeleton } \\
\hline CALD1 & Caldesmon 1 & $\begin{array}{l}\text { Calmodulin- and actin-binding protein that plays an essential role } \\
\text { in the regulation of actin/myosin interactions. }\end{array}$ \\
\hline \multicolumn{3}{|c|}{ Transcription/Translation Regulation } \\
\hline ILF2 & Interleukin enhancer-binding factor 2 & $\begin{array}{c}\text { Transcription factor, also involved in RNA transfer from the } \\
\text { nucleus to the cytoplasm }\end{array}$ \\
\hline RPS2 & $40 \mathrm{~S}$ ribosomal protein $\mathrm{S} 2$ & Ribosome component, small subunit \\
\hline RPS6 & $40 \mathrm{~S}$ ribosomal protein $\mathrm{S} 6$ & $\begin{array}{l}\text { Ribosome component, small subunit, involved in the selective } \\
\text { translation of particular classes of mRNA }\end{array}$ \\
\hline RPS20 & 40 S ribosomal protein $\mathrm{S} 20$ & Ribosome component, small subunit \\
\hline RPL18A & $60 \mathrm{~S}$ ribosomal protein L18a & Ribosome component, large subunit \\
\hline RPL22 & $60 S$ ribosomal protein $\mathrm{L} 22$ & Ribosome component, large subunit \\
\hline SEC61A1 & $\begin{array}{l}\text { Protein transport protein Sec61 subunit alpha } \\
\text { isoform } 1\end{array}$ & $\begin{array}{c}\text { Plays a crucial role in the insertion of secretory and membrane } \\
\text { polypeptides into the ER. }\end{array}$ \\
\hline \multicolumn{3}{|c|}{ Ionic balance regulation } \\
\hline ANXA6 & Annexin A6 & Regulate the release of $\mathrm{Ca} 2+$ from intracellular stores. \\
\hline \multicolumn{3}{|c|}{ Interaction between the cell and its environment } \\
\hline CD151 & CD151 antigen & $\begin{array}{c}\text { Cell surface protein, involved in adhesion, mobility, integrin } \\
\text { trafficking }\end{array}$ \\
\hline
\end{tabular}


Table 2. Cont.

\begin{tabular}{|c|c|c|}
\hline B: DOWNREGUL & & \\
\hline Acronym & Name & Function \\
\hline \multicolumn{3}{|c|}{ Energy metabolism } \\
\hline SLC16A3 & Monocarboxylate transporter 4 & Monocarboxylate transporter 4 \\
\hline GBE1 & 1,4-alpha-glucan-branching enzyme & 1,4-alpha-glucan-branching enzyme \\
\hline \multicolumn{3}{|c|}{ Nucleotide biosynthesis } \\
\hline PAICS & Multifunctional protein ADE2 & Multifunctional protein ADE2 \\
\hline CTPS1 & CTP synthase 1 & CTP synthase 1 \\
\hline \multicolumn{3}{|c|}{ Interaction between the cell and its environment } \\
\hline EMP3 & Epithelial membrane protein 3 & Epithelial membrane protein 3 \\
\hline \multicolumn{3}{|c|}{ RedOx regulation } \\
\hline GSTP1 & Glutathione S-transferase P & Glutathione S-transferase P \\
\hline
\end{tabular}

Table 3. Proteins which expression was altered between $\mathrm{H} 3$ and H6.

\begin{tabular}{|c|c|c|}
\hline A: UPREGULATED & & \\
\hline Acronym & Name & Function \\
\hline \multicolumn{3}{|c|}{ Cytoskeleton } \\
\hline S100A6 & Protein S100-A6 & $\begin{array}{l}\text { Calcium sensor and modulator. Indirectly play a role in the } \\
\text { reorganization of the actin cytoskeleton and in cell motility. }\end{array}$ \\
\hline \multicolumn{3}{|c|}{ Transcription/Translation Regulation } \\
\hline RPS11 & $40 \mathrm{~S}$ ribosomal protein S11 & Ribosome component, small subunit \\
\hline RPL7 & $60 S$ ribosomal protein $\mathrm{L} 7$ & Ribosome component, large subunit \\
\hline TGM2 & Protein-glutamine gamma-glutamyltransferase 2 & $\begin{array}{c}\text { Catalyzes the cross-linking of proteins and the conjugation of } \\
\text { polyamines to proteins. }\end{array}$ \\
\hline \multicolumn{3}{|c|}{ Ionic balance regulation } \\
\hline S100A6 & Protein S100-A6 & $\begin{array}{l}\text { Calcium sensor and modulator. Indirectly play a role in the } \\
\text { reorganization of the actin cytoskeleton and in cell motility. }\end{array}$ \\
\hline \multicolumn{3}{|c|}{ Energy Metabolism } \\
\hline TKT & Transketolase & NADP metabolic process. \\
\hline TBC1D4 & TBC1 domain family member 4 & $\begin{array}{l}\text { Can promote glucose transporter SLC2A4/GLUT4 } \\
\text { translocation at the plasma membrane, thus increasing } \\
\text { glucose uptake }\end{array}$ \\
\hline \multicolumn{3}{|l|}{ B: DOWNREGULATED } \\
\hline Acronym & Name & Function \\
\hline \multicolumn{3}{|c|}{ Cytoskeleton } \\
\hline PLEC & Plectin & $\begin{array}{l}\text { Interlinks intermediate filaments with microtubules and } \\
\text { microfilaments. Anchors intermediate filaments to } \\
\text { desmosomes or hemidesmosomes. }\end{array}$ \\
\hline \multicolumn{3}{|c|}{ Transcription/Translation Regulation } \\
\hline RPS4X & $40 \mathrm{~S}$ ribosomal protein $\mathrm{S} 4, \mathrm{X}$ isoform & Ribosome component, large subunit \\
\hline RPL22 & $60 S$ ribosomal protein L22 & Ribosome component, large subunit \\
\hline PDIA4 & Protein disulfide-isomerase A4 & Catalyzes the rearrangement of -S-S- bonds in proteins. \\
\hline \multicolumn{3}{|c|}{ Interaction between the cell and its environment } \\
\hline CD151 & CD151 antigen & $\begin{array}{l}\text { Essential for the proper assembly of the glomerular and } \\
\text { tubular basement membranes in the kidney. }\end{array}$ \\
\hline
\end{tabular}


Table 4. Proteins which expression was altered between H6 and H12.

\begin{tabular}{|c|c|c|}
\hline A: UPREGULA] & & \\
\hline Acronym & Name & Function \\
\hline \multicolumn{3}{|c|}{ Cytoskeleton } \\
\hline MSN & Moesin & $\begin{array}{l}\text { Member of the ERM family, functions as cross-linkers between plasma } \\
\text { membranes and actin-based cytoskeletons }\end{array}$ \\
\hline $\mathrm{ZYX}$ & Zyxin & $\begin{array}{l}\text { Mediates adhesion-stimulated changes in gene expression and } \\
\text { modulates the organization of actin bundles. }\end{array}$ \\
\hline \multicolumn{3}{|c|}{ Transcription/Translation Regulation } \\
\hline RPS4X & $40 S$ ribosomal protein $\mathrm{S} 4, \mathrm{X}$ isoform & Ribosome component, small subunit \\
\hline RPS15 & $40 S$ ribosomal protein S15 & Ribosome component, small subunit \\
\hline RTN4 & Reticulon-4 & $\begin{array}{l}\text { Regulates membrane morphogenesis in the ER, nuclear pore complex } \\
\text { formation, and proper localization of inner nuclear membrane proteins }\end{array}$ \\
\hline EEF1G & Elongation factor 1-gamma & $\begin{array}{l}\text { Probably plays a role in anchoring the complex to other cellular } \\
\text { components, translational elongation }\end{array}$ \\
\hline \multicolumn{3}{|c|}{ Interaction between the cell and its environment } \\
\hline CLTC & Clathrin heavy chain 1 & $\begin{array}{c}\text { Clathrin is the major protein of the polyhedral coat of coated pits and } \\
\text { vesicles. }\end{array}$ \\
\hline ZYX & Zyxin & $\begin{array}{l}\text { Mediates adhesion-stimulated changes in gene expression and } \\
\text { modulates the organization of actin bundles. }\end{array}$ \\
\hline \multicolumn{3}{|c|}{ B: DOWNREGULATED } \\
\hline Acronym & Name & Function \\
\hline \multicolumn{3}{|c|}{ Intracellular Transport } \\
\hline SLC7A5 & $\begin{array}{l}\text { Large neutral amino acids transporter } \\
\text { small subunit } 1\end{array}$ & High-affinity transport of large neutral amino acids. \\
\hline TMED2 & $\begin{array}{c}\text { Transmembrane emp24 } \\
\text { domain-containing protein } 2\end{array}$ & Involved in vesicular protein trafficking. \\
\hline \multicolumn{3}{|c|}{ Interaction between the cell and its environment } \\
\hline FN1 & Fibronectin & Involved in cell adhesion, cell motility, and maintenance of cell shape. \\
\hline
\end{tabular}

Table 5. Proteins which expression was altered between H12 and H19.

\begin{tabular}{|c|c|c|}
\hline A: UPREGULATED & & \\
\hline Acronym & Name & Function \\
\hline \multicolumn{3}{|c|}{ Energy metabolism } \\
\hline PSAP & Prosaposin & $\begin{array}{l}\text { Localize primarily to the lysosomal compartment where they } \\
\text { facilitate the catabolism of glycosphingolipids with short } \\
\text { oligosaccharide groups. }\end{array}$ \\
\hline PRKCSH & Glucosidase 2 subunit beta & Regulatory subunit of glucosidase II \\
\hline \multicolumn{3}{|c|}{ Transcription/Translation Regulation } \\
\hline ILF2 & Interleukin enhancer-binding factor 2 & $\begin{array}{l}\text { Transcription factor, also involved in RNA transfer from the } \\
\text { nucleus to the cytoplasm }\end{array}$ \\
\hline \multicolumn{3}{|c|}{ Interaction between the cell and its environment } \\
\hline ITGB1 & Integrin beta-1 & Receptors for collagen. \\
\hline \multicolumn{3}{|c|}{ Intracellular Transport } \\
\hline SLC7A5 & $\begin{array}{l}\text { Large neutral amino acids transporter small } \\
\text { subunit } 1\end{array}$ & High-affinity transport of large neutral amino acids. \\
\hline
\end{tabular}


Table 5. Cont.

\begin{tabular}{|c|c|c|}
\hline B: DOWNREGUL & & \\
\hline Acronym & Name & Function \\
\hline \multicolumn{3}{|c|}{ Energy metabolism } \\
\hline TKT & Transketolase & NADP metabolic process. \\
\hline PYGB & Glycogen phosphorylase, brain form & $\begin{array}{c}\text { Glycogen phosphorylase that regulates glycogen } \\
\text { mobilization }\end{array}$ \\
\hline \multicolumn{3}{|c|}{ Interaction between the cell and its environment } \\
\hline ANXA2 & Annexin A2 & Regulates membrane budding, membrane raft assembly \\
\hline $\mathrm{ZYX}$ & Zyxin & Adhesion plaque protein. \\
\hline FERMT2 & Fermitin family homolog 2 & $\begin{array}{l}\text { Scaffolding protein that enhances integrin activation } \\
\text { mediated by TLN1 and/or TLN2, but activates integrins only } \\
\text { weakly by itself. }\end{array}$ \\
\hline \multicolumn{3}{|c|}{ Cytoskeleton } \\
\hline TAGLN2 & Transgelin 2 & Actin filament binding, the possible regulatory role \\
\hline MSN & Moesin & $\begin{array}{l}\text { Member of the ERM family, functions as cross-linkers } \\
\text { between plasma membranes and actin-based cytoskeletons }\end{array}$ \\
\hline S100A11 & S100 Calcium Binding Protein A11 & $\begin{array}{l}\text { This protein may function in motility, invasion, and tubulin } \\
\text { polymerization. }\end{array}$ \\
\hline CAP1 & Adenylyl cyclase-associated protein 1 & $\begin{array}{l}\text { Directly regulates filament dynamics, implicated in mRNA } \\
\text { localization and the establishment of cell polarity. }\end{array}$ \\
\hline IQGAP1 & Ras GTPase-activating-like protein IQGAP1 & $\begin{array}{l}\text { Serves as an assembly scaffold for the organization of the } \\
\text { actin cytoskeleton at the plasma membrane. }\end{array}$ \\
\hline FSCN1 & Fascin Actin-Bundling Protein 1 & $\begin{array}{l}\text { Fascin proteins organize F-actin into parallel bundles and are } \\
\text { required for the formation of actin-based cellular protrusions. }\end{array}$ \\
\hline \multicolumn{3}{|c|}{ Ionic balance regulation } \\
\hline AHNAK & AHNAK Nucleoprotein & $\begin{array}{c}\text { May be required for neuronal cell differentiation. regulation } \\
\text { of RNA splicing }\end{array}$ \\
\hline \multicolumn{3}{|c|}{ Transcription/Translation Regulation } \\
\hline EEF1A1P5 & $\begin{array}{l}\text { Eukaryotic Translation Elongation Factor } 1 \\
\text { Alpha } 1 \text { Pseudogene } 5\end{array}$ & Translation elongation factor \\
\hline EEF1G & Elongation factor 1-gamma & Translation elongation factor \\
\hline RPS13 & $40 \mathrm{~S}$ ribosomal protein $\mathrm{S} 13$ & Ribosome component, small subunit \\
\hline RPS15 & $40 \mathrm{~S}$ ribosomal protein $\mathrm{S} 15$ & Ribosome component, small subunit \\
\hline RPS24 & 40 S ribosomal protein S24 & Ribosome component, small subunit \\
\hline RPL18 & $60 \mathrm{~S}$ ribosomal protein $\mathrm{L} 18$ & Ribosome component, large subunit \\
\hline RPL13 & $60 \mathrm{~S}$ ribosomal protein $\mathrm{L} 13$ & Ribosome component, large subunit \\
\hline SARS & Serine-tRNA ligase, cytoplasmic & Catalyzes the attachment of serine to tRNA(Ser). \\
\hline РABPC4 & Polyadenylate-binding protein 4 & $\begin{array}{c}\text { May be involved in cytoplasmic regulatory processes of } \\
\text { mRNA metabolism. }\end{array}$ \\
\hline \multicolumn{3}{|c|}{ Intracellular Transport } \\
\hline ARF4 & ADP Ribosylation Factor 4 & $\begin{array}{l}\text { Plays a role in vesicular trafficking and as an activator of } \\
\text { phospholipase D }\end{array}$ \\
\hline DYNC1H1 & Cytoplasmic dynein 1 heavy chain 1 & $\begin{array}{c}\text { Acts as a motor for the intracellular retrograde motility of } \\
\text { vesicles and organelles along microtubules. }\end{array}$ \\
\hline \multicolumn{3}{|c|}{ RedOx regulation } \\
\hline PRDX6 & Peroxiredoxin-6 & Involved in redox regulation of the cell \\
\hline
\end{tabular}


Table 6. Proteins which expression was altered between H19 and H24.

\begin{tabular}{|c|c|c|}
\hline A: UPREGULA & & \\
\hline Acronym & Name & Function \\
\hline \multicolumn{3}{|c|}{ Cytoskeleton } \\
\hline S100A6 & Protein S100-A6 & $\begin{array}{l}\text { Calcium sensor and modulator. Indirectly play a role in the } \\
\text { reorganization of the actin cytoskeleton and in cell motility. }\end{array}$ \\
\hline \multicolumn{3}{|c|}{ Transcription/Translation Regulation } \\
\hline H2AFX & H2A Histone Family Member X & $\begin{array}{c}\text { Variant histone } \mathrm{H} 2 \mathrm{~A} \text { that replaces conventional } \mathrm{H} 2 \mathrm{~A} \text { in a subset of } \\
\text { nucleosomes. }\end{array}$ \\
\hline \multicolumn{3}{|c|}{ Ionic balance regulation } \\
\hline S100A6 & Protein S100-A6 & $\begin{array}{l}\text { Calcium sensor and modulator. Indirectly play a role in the } \\
\text { reorganization of the actin cytoskeleton and in cell motility. }\end{array}$ \\
\hline \multicolumn{3}{|c|}{ B: DOWNREGULATED } \\
\hline Acronym & Name & Function \\
\hline \multicolumn{3}{|c|}{ Energy metabolism } \\
\hline TBC1D4 & TBC1 domain family member 4 & $\begin{array}{l}\text { Can promote glucose transporter SLC2A4/GLUT4 translocation at } \\
\text { the plasma membrane, thus increasing glucose uptake }\end{array}$ \\
\hline \multicolumn{3}{|c|}{ Cytoskeleton } \\
\hline SPTBN1 & Spectrin beta chain, non-erythrocytic 1 & $\begin{array}{l}\text { Spectrin is an actin crosslinking and molecular scaffold protein that } \\
\text { links the plasma membrane to the actin cytoskeleton. }\end{array}$ \\
\hline PDLIM7 & PDZ and LIM domain protein 7 & $\begin{array}{l}\text { May function as a scaffold on which the coordinated assembly of } \\
\text { proteins can occur. }\end{array}$ \\
\hline SNU13 & Spectrin alpha chain, non-erythrocytic 1 & $\begin{array}{l}\text { Spectrin is an actin crosslinking and molecular scaffold protein that } \\
\text { links the plasma membrane to the actin cytoskeleton. }\end{array}$ \\
\hline \multicolumn{3}{|c|}{ Transcription/Translation Regulation } \\
\hline EEF1G & Elongation factor 1-gamma & Translation elongation factor \\
\hline RPS2 & $40 \mathrm{~S}$ ribosomal protein $\mathrm{S} 2$ & Ribosome component, small subunit \\
\hline RPS11 & $40 S$ ribosomal protein $\mathrm{S} 11$ & Ribosome component, small subunit \\
\hline RPL7 & $60 \mathrm{~S}$ ribosomal protein $\mathrm{L} 7$ & Ribosome component, large subunit \\
\hline ILF2 & Interleukin enhancer-binding factor 2 & $\begin{array}{l}\text { Transcription factor, also involved in RNA transfer from the } \\
\text { nucleus to the cytoplasm }\end{array}$ \\
\hline \multicolumn{3}{|c|}{ Proteasome } \\
\hline PSMD3 & $\begin{array}{l}26 \mathrm{~S} \text { proteasome non-ATPase regulatory } \\
\text { subunit } 3\end{array}$ & $\begin{array}{c}\text { Component of the } 26 \mathrm{~S} \text { proteasome, a multiprotein complex } \\
\text { involved in the ATP-dependent degradation of ubiquitinated } \\
\text { proteins. }\end{array}$ \\
\hline
\end{tabular}

Table 7. Proteins which expression was altered between H24 and R6.

\begin{tabular}{|c|c|c|}
\hline A: UPREGULA & & \\
\hline \multicolumn{3}{|l|}{ None. } \\
\hline \multicolumn{3}{|c|}{ B: DOWNREGULATED } \\
\hline Acronym & Name & Function \\
\hline \multicolumn{3}{|c|}{ Energy metabolism } \\
\hline GAPDH & Glyceraldehyde-3-phosphate dehydrogenase & $\begin{array}{c}\text { Catalyzes the reversible oxidative phosphorylation of } \\
\text { glyceraldehyde-3-phosphate in the presence of inorganic phosphate and } \\
\text { nicotinamide adenine dinucleotide. }\end{array}$ \\
\hline ALDOA & Fructose-bisphosphate aldolase A & Plays a key role in glycolysis and gluconeogenesis. \\
\hline \multicolumn{3}{|c|}{ Interaction between the cell and its environment } \\
\hline FN1 & Fibronectin & Involved in cell adhesion, cell motility, and maintenance of cell shape. \\
\hline CLTC & Clathrin heavy chain 1 & $\begin{array}{c}\text { Clathrin is the major protein of the polyhedral coat of coated pits and } \\
\text { vesicles. }\end{array}$ \\
\hline
\end{tabular}


Table 7. Cont.

\begin{tabular}{|c|c|c|}
\hline B: DOWNREGULA' & & \\
\hline Acronym & Name & Function \\
\hline \multicolumn{3}{|c|}{ Cytoskeleton } \\
\hline MYH9 & Myosin-9 & $\begin{array}{l}\text { Plays a role in cytokinesis, cell shape, and specialized functions such as } \\
\text { secretion and capping. During cell spreading, plays an important role in } \\
\text { cytoskeleton reorganization, focal contacts formation, and lamellipodial } \\
\text { retraction; this function is mechanically antagonized by MYH10 }\end{array}$ \\
\hline FLNA & Filamin-A & $\begin{array}{l}\text { Promotes orthogonal branching of actin filaments and links actin } \\
\text { filaments to membrane glycoproteins }\end{array}$ \\
\hline CFL1 & Cofilin-1 & $\begin{array}{c}\text { Binds to F-actin and exhibits } \mathrm{pH} \text {-sensitive F-actin depolymerizing activity. } \\
\text { Regulates actin cytoskeleton dynamics. }\end{array}$ \\
\hline SPTAN1 & Spectrin beta chain, non-erythrocytic 1 & $\begin{array}{l}\text { Spectrin is an actin crosslinking and molecular scaffold protein that links } \\
\text { the plasma membrane to the actin cytoskeleton. }\end{array}$ \\
\hline SPTBN1 & Spectrin beta chain, non-erythrocytic 1 & $\begin{array}{l}\text { Spectrin is an actin crosslinking and molecular scaffold protein that links } \\
\text { the plasma membrane to the actin cytoskeleton. }\end{array}$ \\
\hline \multicolumn{3}{|c|}{ Ionic balance regulation } \\
\hline AHNAK & AHNAK Nucleoprotein & $\begin{array}{l}\text { May be required for neuronal cell differentiation. regulation of RNA } \\
\text { splicing }\end{array}$ \\
\hline \multicolumn{3}{|c|}{ Transcription/Translation Regulation } \\
\hline EEF1A1P5 & $\begin{array}{c}\text { Eukaryotic Translation Elongation Factor } 1 \text { Alpha } 1 \\
\text { Pseudogene } 5\end{array}$ & Translation elongation factor \\
\hline HNRNPA2B1 & Heterogeneous nuclear ribonucleoproteins A2/B1 & $\begin{array}{l}\text { Heterogeneous nuclear ribonucleoprotein (hnRNP) that associates with } \\
\text { nascent pre-mRNAs, packaging them into hnRNP particles }\end{array}$ \\
\hline HNRNPD & Heterogeneous nuclear ribonucleoprotein D0 & $\begin{array}{l}\text { Heterogeneous nuclear ribonucleoprotein (hnRNP) that associates with } \\
\text { nascent pre-mRNAs, packaging them into hnRNP particles }\end{array}$ \\
\hline IPO5 & Importin-5 & Functions in nuclear protein import as nuclear transport receptor. \\
\hline PTRF & Caveolae Associated Protein 1 & $\begin{array}{l}\text { Enables the dissociation of paused ternary polymerase I transcription } \\
\text { complexes from the } 3^{\prime} \text { end of pre-rRNA transcripts. }\end{array}$ \\
\hline PTBP1 & Polypyrimidine tract-binding protein 1 & $\begin{array}{l}\text { Plays a role in pre-mRNA splicing and in the regulation of alternative } \\
\text { splicing events. }\end{array}$ \\
\hline RPS2 & $40 \mathrm{~S}$ ribosomal protein $\mathrm{S} 2$ & Ribosome component, small subunit \\
\hline RPS4X & $40 \mathrm{~S}$ ribosomal protein $\mathrm{S} 4, \mathrm{X}$ isoform & Ribosome component, small subunit \\
\hline RPS5 & $40 \mathrm{~S}$ ribosomal protein S5 & Ribosome component, small subunit \\
\hline RPS8 & $40 \mathrm{~S}$ ribosomal protein $\mathrm{S} 8$ & Ribosome component, small subunit \\
\hline RPS13 & $40 \mathrm{~S}$ ribosomal protein $\mathrm{S} 13$ & Ribosome component, small subunit \\
\hline RPL3 & $60 S$ ribosomal protein L3 & Ribosome component, large subunit \\
\hline RPL4 & $60 S$ ribosomal protein $\mathrm{L} 4$ & Ribosome component, large subunit \\
\hline RPL6 & $60 S$ ribosomal protein L6 & Ribosome component, large subunit \\
\hline RPL7 & $60 S$ ribosomal protein L7 & Ribosome component, large subunit \\
\hline RPL13 & $60 S$ ribosomal protein $\mathrm{L} 13$ & Ribosome component, large subunit \\
\hline RPL18 & $60 S$ ribosomal protein L18 & Ribosome component, large subunit, involved in translational initiation \\
\hline RPL18A & $60 S$ ribosomal protein $\mathrm{L} 18 \mathrm{a}$ & Ribosome component, large subunit \\
\hline RPL23 & $60 S$ ribosomal protein $\mathrm{L} 23$ & $\begin{array}{c}\text { Ribosome component, large subunit, possesses ubiquitin ligase inhibitor } \\
\text { activity }\end{array}$ \\
\hline RPL28 & $60 S$ ribosomal protein $\mathrm{L} 28$ & $\begin{array}{l}\text { Ribosome component, large subunit, positive regulation of protein } \\
\text { targeting to the mitochondrion, regulation of mitophagy }\end{array}$ \\
\hline SSB & Ribosome-associated molecular chaperone SSB1 & $\begin{array}{l}\text { Ribosome-bound, Hsp70-type chaperone that assists in the } \\
\text { cotranslational folding of newly synthesized proteins in the cytosol. }\end{array}$ \\
\hline HSPB1 & Heat shock protein beta-1 & $\begin{array}{l}\text { Functions as a molecular chaperone probably maintaining denatured } \\
\text { proteins in a folding-competent state }\end{array}$ \\
\hline H2AFX & H2A Histone Family Member X & $\begin{array}{l}\text { Variant histone } \mathrm{H} 2 \mathrm{~A} \text { replaces conventional } \mathrm{H} 2 \mathrm{~A} \text { in a subset of } \\
\text { nucleosomes. }\end{array}$ \\
\hline ILF2 & Interleukin enhancer-binding factor 2 & $\begin{array}{l}\text { may regulate transcription of the IL2 gene during T-cell activation. It can } \\
\text { also promote the formation of stable DNA-dependent protein kinase } \\
\text { holoenzyme complexes on DNA. }\end{array}$ \\
\hline PABPC4 & Polyadenylate-binding protein 4 & $\begin{array}{c}\text { May be involved in cytoplasmic regulatory processes of mRNA } \\
\text { metabolism. }\end{array}$ \\
\hline SND1 & Staphylococcal nuclease domain-containing protein & $\begin{array}{l}\text { Functions as a bridging factor between STAT6 and the basal transcription } \\
\text { factor. }\end{array}$ \\
\hline
\end{tabular}




\section{Discussion}

We describe herein an attempt at exploring the proteomic implications of cold ischemia at the cellular level. To our knowledge, this is the first study of its kind. We used a simple model of in vitro cold ischemia, mimicking the conditions withstood by an organ during transport, namely: hypothermia $\left(4{ }^{\circ} \mathrm{C}\right)$, anoxia and preservation solution (UW). We used a primary culture of endothelial cells, as these represent the first cell impacted by IR. While this limits the scope of our study in terms of complexity, the simplicity of the model is a strength in terms of reproducibility. Moreover, in our hands, this model has been used to test compounds against IR before full preclinical testing on large animals, and the level of superposition between in vitro and in vivo results was significant $[7,21,22]$.

We first processed the data using a heatmap. There was a large number of motifs for which expression was not altered. These belonged to ontologies related to protein production, folding, and transport as well as energy metabolism. This suggests that even though extreme conditions of temperature and oxygen pressure, the cell retains a general array of proteins in pathways that are central to its survival. Thus, alteration of its physiology will likely take place through either expression modulation in key elements of the chain, or post-translational regulation (phosphorylation, cleavage, etc.).

We next focused on proteins specifically modulated by our conditions. To this end, we used Cytoscape's ClueGo application [23]. This showed that while several families were common between the time points, there were individual differences. This implies that cold ischemia not only changes the proteome by turning off certain pathways and inducing new ones but also alters the protein present within the same regulatory pathway, hence reprogramming it. We recorded four ontologies that were majorly impacted: Cytoskeleton, Transcription/Translation Regulation, Ionic Balance Regulation, and Energy metabolism. The first three demonstrated a similar pattern, albeit with different timing: heightened protein expression in the first hours of the procedure, followed by maintenance of this expression then collapse after a certain time point. This implies that the cell is capable of de novo expression of proteins, even while subjected to hypothermia and anoxia, but that each ontology has either differing energy needs or a differing priority in terms of cell health. Observing the general variations in protein expression, it appears that $12 \mathrm{~h}$ represents a key limit in our model, after which we observe major downregulations. Interestingly, in our hands, $12 \mathrm{~h}$ is the preservation time after which reperfusion induces cell death, with an intensity proportional to the time of preservation [24]. This is concordant with the now well-defined correlation between cold ischemia time, ischemia-reperfusion, and long-term adverse outcomes [25].

Several protein motifs were singled out during the analysis.

Regarding the cytoskeleton, the impact on Plectin, which affects mechanical as well as dynamic properties of the cytoskeleton [26], is coherent considering the observed impact of organ preservation conditions on cell polarity and cytoskeleton [27]. S100A6 was one of the few proteins that constantly increased, likely due to its role in regulating a wide array of cellular and molecular functions, including cell proliferation, differentiation, and survival as well as $\mathrm{Ca}^{2+}$ dynamics [28]. Indeed, S100A6 has been functionally linked to changes in cellular motility and cytoskeletal reorganization [29], and S100A6 gene therapy improved survival, infarct size, and viability in acute heart I/R injury models [30]. This target could thus be an interesting avenue of research to improve graft quality.

Regarding motifs belonging to the Transcription/Translation ontology, the fact that ribosome subunits were impacted is an intriguing aspect of our results, indeed ribosomes composition is seldom considered. However, not all mRNA are considered equal by ribosomes, and some RNA molecules are only translated under altered conditions, as in the case of internal ribosome entry sites [31] or upstream open reading frames [32] mRNAs. Hence, it is likely that ribosome subunit composition alters the affinity for different mRNAs and favors the translation of specific ones. Moreover, ribosome composition may also affect ATP consumption [33], an area yet little explored, which could unveil interesting mechanisms of adaptation to low ATP conditions such as found during ischemia. Passive 
selection of proteins through decreased ATP availability, possibly through ribosome reconfiguration, could represent an interesting area of future research in cellular adaptation and survival.

Other interesting motifs in this ontology were: ILF2, involved in the regulatory subunit of NF90/NF110 complexes, themselves implicated in mitotic control [34], and RNA metabolism aspects such as transcription, transport, stability, and translation [35]. ILF2 interacts with RNA-binding proteins (RBPs) involved in DNA repair, genome stability maintenance, and DNA damage response [36]. Its early overexpression and long maintenance suggest a central involvement of this protein in preservation injury. EEF1G functions in the transport of aminoacyl tRNAs to the ribosome for protein synthesis. Interestingly, EEF1G also plays a role as a transcription factor, through interaction with the RNA polymerase II and shuttling or nursing mRNA [37]. Moreover, the N-terminal region of the eEF1G protein contains a glutathione transferase domain [38], which could play an active role in glutathione usage as a defense mechanism. Maintenance of its expression at the beginning of the procedure highlights its role in RNA translation, and the peak of expression before $12 \mathrm{~h}$ underlines the importance of this time point in regard to survival. - $\mathrm{H} 2 \mathrm{~A}$ is particularly involved in the identification of DNA breaks [39] and in hypoxic situations, it promotes endothelial cell proliferation and is necessary for proper neovascularization [40]. This suggests that DNA protection remains a priority for the cell to the very end and that H2AFX could be an interesting target for organ evaluation and therapy.

Among Energy Metabolism ontology motifs we identified: TKT, which activity is increased in cells with heightened energy needs, such as cancer cells [41], while knockdown of TKT suppresses NAPDH production, increases ROS production, and inhibits the cell cycle [42]. Interestingly, the TKT promoter contains multiple stress-inducible control sequences [43]. Hence, TKT alteration could represent the answer of the cell to the extreme change in conditions and its impact on energy metabolism motifs recorded between 0 and $3 \mathrm{~h}$ and could be a precious pathway to investigate to improve preservation quality. TBC1D4, which controls intracellular trafficking of protein-bearing membrane vesicles [44], among which the glucose transporter GLUT4 [45]. It also interacts with the $\mathrm{Na}^{+}-\mathrm{K}^{+}$-ATPase $\alpha$-subunit, inducing intracellular retention of the $\mathrm{Na}^{+}-\mathrm{K}^{+}$-ATPase, targeting ionic balance [46,47]. Its modulation suggests that the cell's answer to stress not only includes reprogramming of the energy metabolism but also favors glucose intake and controlled ionic balance. PSAP, located in lysosomes and enhancing lysosomal hydrolytic activities, notably the degradation of glycosphingolipids into short oligosaccharides; while it also functions extracellularly as an activator of the Akt and ERK pathways [48] and can protect the cell against oxidative stress-induced cell death [49]. PSAP was one of the few proteins to be upregulated between 12 and $19 \mathrm{~h}$, likely representing an effort from the cell to obtain energy from any available resource, as well as promote survival through paracrine mechanisms.

Finally, within the ionic balance regulation ontology, we identified: -AHNAK, involved in the maintenance of the structural and functional organization of the subsarcolemmal cytoarchitecture [50], located within specific vesicles called "enlargosomes," and is redistributed to the external surface of the plasma membrane in response to large increases in $\mathrm{Ca}^{2+}$, participating in cell membrane differentiation and repair [51]. Regulation of $\mathrm{AH}-$ NAK after $12 \mathrm{~h}$ suggests that this protein could be directly involved in the ability of the cell to withstand the harsh conditions of preservation and a key factor in the " $12 \mathrm{~h} \mathrm{limit"} \mathrm{after}$ which organ quality collapses. -ANXA6, participates in the transduction of intracellular $\mathrm{Ca}^{2+}$ which, along with acidic $\mathrm{pH}$ and cholesterol, regulates the membrane targeting for this annexin [52], where it functions as membrane organizer and channel modulator [53]. We observe upregulated as soon as the cell was subjected to organ preservation conditions, likely related to $\mathrm{pH}$ alterations, and it remained unchanged $12 \mathrm{~h}$ of preservation, hinting towards a role as a factor in the " $12 \mathrm{~h}$ limit" discussed above.

Our results highlight the fact that cold ischemia cannot be assimilated to a simple slowing down of the cell metabolism. Indeed, in-depth changes take place within the pro- 
teome, with the reprogramming of major areas such as the cytoskeleton, energy metabolism, and ionic balance. Furthermore, we demonstrate that this injury impacted the proteinproducing machinery at every step of the process, from DNA folding to RNA maturation and ribosome composition and regulation. Our results show an interesting degree of similarity with a previous study from our group in which we performed transcriptomic analysis of the kidney after warm ischemia (more than 100 altered transcripts) and after subsequent cold storage (more than 400 altered transcripts) [54]. One of the findings was that several RNA coding for proteins involved in protein folding were upregulated (for instance Heat shock protein $70 \mathrm{kDa}$ and thioredoxin-related transmembrane protein 4) and the proteasome (for instance Proteasomal ATPase-associated factor 1) [54], highlighting that ischemia did indeed induce the protein production and quality check machinery. Several parallels can be drawn between the two studies. Cytoskeleton: several transcripts of the Rho family GTPases were altered. Transcription/Translation: elements of the chain, for instance, several histones (also observed herein): Histone cell cycle regulator (HIRA) and Histones 2A and 4, as well as DNA damage response machinery (Early growth response protein 1, Kruppel-like factor-4 and Polo-like kinase 3) and RNA metabolism (RNA methylation PAF1 complex). Energy metabolism: here also, several transcripts were regulated, such as elements of the MAPK pathways.

While the models were different (in vitro culture herein and porcine kidneys in the transcriptome study), the interesting degree of concordance between the result sets suggests some level of conservation in the pathways induced by ischemia-reperfusion. Such an intermediate level of concordance between the studies may be due to one of the limits of our study, namely the fact that we focused on a single cell type, cultured in 2D. This scale limitation permitted a high level of control over sample time and sample concordance, but significance can be lost. Specific programs, both in terms of endothelial cell origin and larger organ experiments, will need to be conducted to consolidate the concepts uncovered herein. Our work opens the possibility to further investigation in models proposing a higher level of sophistication [55]. Such a model would permit for instance to mimic perfusion, such as with microfluidic chambers, as the use of machine perfusion is increasing, particularly for marginal donors, and provide answers to the rising interest in designing novel therapeutics compatible with this mode of preservation [56]. Further complexification could include multiple cell types constructs, such as co-culture of primary cells or the higher sophistication of organoids [57], which could also be included in microfluidic chambers, paving the way for the reproduction of the level of complexity found in animals, using circulating cells to reproduce the first stage of immune activation.

Another limit is that we did not perform reperfusion at every time point studied, hence could not evaluate cell recovery for each level of ischemia. Indeed, due to the amount of data generated and quantity of work required to perform these analyses, we focused on the kinetics of ischemia, with a special interest in exploring the relationship between time and impact, as recent work has hinted towards a "threshold" after which organ quality rapidly degrades. We indeed performed reperfusion experiments in which ischemia time was gradually increased, with the same cells, and demonstrated that a shift was occurring between 6 and $12 \mathrm{~h}$ [24]. Endeavoring to explore this shift herein, our experiments brought further clarification to the "12-h limit". However, further definition of this time limit will have to be explored with models of both ischemia and reperfusion, to determine the consequences of the observed proteomic changes on cell phenotype post-reperfusion to contribute to the improvement of organ monitoring strategies.

While it has been described that ischemia has an impact on the mitochondria [58,59] and the cytoskeleton [60], with the effects on ionic imbalance, have been explored elsewhere [17], our work provides the opportunity to integrate these pathways in a kinetic fashion along the length of $24 \mathrm{~h}$ ischemia, a duration compatible with standard clinical times. Moreover, the well-described association between these pathways and cell death pathways (apoptosis, necrosis) as well as the activation of the immune system [61] provides increased quality to the description of ischemia-reperfusion injury, a key issue in transplantation as well as 
other pathologies. Among these pathways, recent work highlights the interplay between NADP and mTOR in survival and protection against ischemia-reperfusion $[62,63]$ as well as the benefits of NADPH supplementation [64]; this is concordant with our results regarding the NADP pathways and the role of TKT. Moreover, we demonstrate that RhoGTPases are impacted, a pathway recently highlighted to play a critical role in kidney disease, notably podocytopathy [65]. Hence, by describing such early pathways affected by ischemia, our results uncover therapeutic possibilities upstream from final pathways such as cell death and immune activation.

After $6 \mathrm{~h}$ of reperfusion, no new proteins were detected, however, we observed an important downregulation of a large number of motifs. Interestingly, the motifs being downregulated had not been detected during hypothermic anoxia. Thus, we may not necessarily observe a retraction of the defense mechanisms put in place during stress, but another reshuffling of priorities: cells having survived the conditions of organ preservation must now repair and regenerate to regain the pre-preservation state.

The parallels between transcriptomics and proteomics results confirm that the cell and the organ are not inactive in response to organ preservation and that pathways exist to increase resiliency and possibly quality, which directly impacts the outcome. Hence, specific programs will need to be designed towards a better understanding of the areas uncovered herein to improve our knowledge of the physiopathological mechanism of IRI and be able to devise new protocols to improve organ resistance and thus the success of transplantation. Finally, data strengthen the fact that ischemia is a key step during the transplantation process with important transcriptional and proteome modifications inducing a full reprogramming of major survival/response pathways.

\section{Materials and Methods}

\subsection{Materials and Sample Preparation}

Primary human renal cortex endothelial cells (HRGEC, CliniSciences, Nanterre, France) were used as previously published [24]. At 80\% confluence and after synchronization (H0), cells were subjected to cold ischemia like conditions: incubation in a hermetic chamber at $4{ }^{\circ} \mathrm{C}$ containing an anoxic atmosphere: $0 \% \mathrm{O}_{2}, 5 \% \mathrm{CO}_{2}$, and $95 \% \mathrm{~N}_{2}$ (Bactal 2 gaz, Air Liquide, Paris, France) during 3, 6, 12, 19 and 24 h (H3, H6, H12, H19, H24), in University of Wisconsin solution (UW, Bridge to Life, London, UK). At the end of the $24 \mathrm{~h}$ conservation period, the cells were washed and incubated in M200/2\% FBS for $6 \mathrm{~h}$ (R6). At each time point, the cells were rapidly washed, scrapped, and frozen until analysis. 3 independent experiments were performed.

Cell pellets were lysed in a trypsin buffer (ThermoFisher, Illkirch, France) and centrifuged to eliminate cellular debris. A $30 \mathrm{kDa}$ cut-off spin column (MerkMillipore, Fontenay sous Bois, France) was used to alleviate noise.

\subsection{LC-MS Parameters}

$5 \mu \mathrm{L}$ of protein extract was injected into a C18 column, $300 \AA \AA, 2.1 \mathrm{~mm} \times 150 \mathrm{~mm}$ (Sigma, Saint-Quentin Fallavier, France) maintained at $60^{\circ} \mathrm{C}$. LC-MS was performed with an Aquity UPLC system connected on-line with a Waters Xevo G2-XS-TOF mass spectrometer (Waters, Guyancourt, France). The following gradient was used at a flow rate of $0.2 \mathrm{~mL} / \mathrm{min}$ : isocratic hold at $5 \% \mathrm{~B}$ for $3 \mathrm{~min}$ followed by three steps of linear increases to $25 \% \mathrm{~B}$ at $4 \mathrm{~min}, 55 \% \mathrm{~B}$ at $34 \mathrm{~min}, 80 \% \mathrm{~B}$ at $36 \mathrm{~min}$, followed by an isocratic hold at $80 \% \mathrm{~B}$ for $9 \mathrm{~min}$. The column was finally equilibrated with $5 \% \mathrm{~B}$ for $10 \mathrm{~min}$ prior to the next run. Solvent A was $99.9 \% \mathrm{H}_{2} \mathrm{O} / 0.1 \%$ formic acid and solvent $\mathrm{B}$ was $90 \% \mathrm{ACN} / 9.9 \% \mathrm{H}_{2} \mathrm{O} / 0.1 \%$ formic acid.

MS source parameters were: ESI capillary voltage $+4.3 \mathrm{kV}$, desolvation temperature $350{ }^{\circ} \mathrm{C}$, cone gas flow rate $10 \mathrm{~L} / \mathrm{min}$, nebulizer pressure $25 \mathrm{psig}$, and fragmentor voltage $250 \mathrm{~V}$. Data were acquired at $1 \mathrm{spectrum} / \mathrm{sec}$, with acquisition window 100 to $3000 \mathrm{~m} / \mathrm{z}$. 


\subsection{Data Analysis}

Raw data were processed using the PLGS software (Protein Lynx Global Server, Waters), interrogating the Uniprot database. As the MS software provided us with a list of uniprot identifiers attached to a signal intensity per sample, we first tackled the issue of normalization. All signals were expressed as a ratio to the mean signal at $\mathrm{H} 0$, to show variation to baseline. Then, selecting the motifs identified in homo sapiens, we adapted a strategy similar to that of the gNorm algorithm in QPCR data management [66]: a shortlist of the most stable proteins was compiled with proteins a) detected in all samples, and b) with the smallest SD (expressed as \% of average signal to average H0). This list counted: VIM, CLTC, LGALS1, PDIA6, PPIA, PFN1, MIF, CD99, P4HA2, SCARB2. Then, signal (ratio to mean $\mathrm{H} 0$ ) from these 10 proteins was log-transformed, normalized by each of the 9 others, the SD calculated for each normalization and the average of these SD was termed " $\mathrm{M}$ ". The 9 proteins with the lowest $\mathrm{M}$ were then selected, and the procedure was repeated until the most stable were identified: VIM et SCARB2. The evolution of M is shown in Supplementary Figure S1. Normalization of each signal was performed with the following formula:

$$
\frac{(\text { signal intensity } \mathrm{H} / \text { moy signal intensity } \mathrm{H} 0)}{\sqrt[f]{\prod_{0}^{f}(\text { ref signal intensity } \mathrm{H} x-\text { moy signal intensity } \mathrm{H} 0)}}
$$

The signal was then $\log 10$ transformed for a better estimation of fold change in either direction.

\subsection{Statistics}

The R software was used for statistical analysis and heatmap generation. The significance of variations from one-time point to the next was evaluated using the non-parametric Mann-Whitney U test. Each time point was repeated 3 times $(\mathrm{N}=3, n=3)$.

Supplementary Materials: The following are available online at https://www.mdpi.com/1422-006 7/22/5/2384/s1, Figure S1: Number of proteins considered.

Author Contributions: Conceptualization, R.T.; data curation, O.P.-C., J.V., S.L.P., M.L., and R.T.; formal analysis, O.P.-C., J.V., W.K., J.-B.W., and R.T.; Investigation, S.G. and R.T.; methodology, N.B., T.H., and R.T.; project administration, R.T.; resources, T.H.; Supervision, R.T.; writing-original draft, R.T.; writing-review and editing, O.P.-C., J.V., S.L.P., M.L., W.K., J.-B.W., S.G., N.B., T.H., and R.T. All authors have read and agreed to the published version of the manuscript.

Funding: Financial support was received from the Région Poitou Charentes, the CHU de Poitiers, the University of Poitiers and the Inserm.

Institutional Review Board Statement: Not applicable.

Informed Consent Statement: Not applicable.

Data Availability Statement: The data presented in this study are available on request from the corresponding author. The data are not publicly available due to the nature of the nature of the experiments and the format of the public repositories.

Acknowledgments: The authors also wish to acknowledge the invaluable technical help from Virigine Ameteau, Maïté Jacquard, and Sandrine Joffrion.

Conflicts of Interest: The authors declare no conflict of interest. 


$\begin{array}{ll}\text { Abbreviations } \\ \text { CIT } & \text { cold ischemia time } \\ \text { DCD } & \text { deceased after circulatory death donors } \\ \text { ECD } & \text { extended criteria donors } \\ \text { HRGEC } & \text { human renal glomerular endothelial cells } \\ \text { IRI } & \text { ischemia reperfusion injury }\end{array}$

\section{References}

1. Rosengard, B.R.; Feng, S.; Alfrey, E.J.; Zaroff, J.G.; Emond, J.C.; Henry, M.L.; Garrity, E.R.; Roberts, J.P.; Wynn, J.J.; Metzger, R.A.; et al. Report of the Crystal City Meeting to Maximize the Use of Organs Recovered from the Cadaver Donor. Am. J. Transplant. 2002, 2, 701-711. [CrossRef] [PubMed]

2. Meier-Kriesche, H.-U.; Schold, J.D.; Srinivas, T.R.; Kaplan, B. Lack of Improvement in Renal Allograft Survival despite a Marked Decrease in Acute Rejection Rates over the Most Recent Era. Am. J. Transplant. 2004, 4, 378-383. [CrossRef] [PubMed]

3. Jamieson, R.W.; Friend, P.J. Organ Reperfusion and Preservation. Front. Biosci. J. Virtual Libr. 2008, 13, 221-235. [CrossRef] [PubMed]

4. Salahudeen, A.K. Cold Ischemic Injury of Transplanted Organs: Some New Strategies against an Old Problem. Am. J. Transplant. 2004, 4, 1. [CrossRef]

5. Salahudeen, A.K. Consequences of Cold Ischemic Injury of Kidneys in Clinical Transplantation. J. Investig. Med. Off. Publ. Am. Fed. Clin. Res. 2004, 52, 296-298.

6. Hauet, T.; Goujon, J.M.; Vandewalle, A.; Baumert, H.; Lacoste, L.; Tillement, J.P.; Eugene, M.; Carretier, M. Trimetazidine Reduces Renal Dysfunction by Limiting the Cold Ischemia/Reperfusion Injury in Autotransplanted Pig Kidneys. J. Am. Soc. Nephrol. 2000, $11,138-148$.

7. Thuillier, R.; Allain, G.; Giraud, S.; Saintyves, T.; Delpech, P.O.; Couturier, P.; Billault, C.; Marchand, E.; Vaahtera, L.; Parkkinen, J.; et al. Cyclodextrin Curcumin Formulation Improves Outcome in a Preclinical Pig Model of Marginal Kidney Transplantation. Am. J. Transplant. 2014, 14, 1073-1083. [CrossRef] [PubMed]

8. Logan, S.R. The Orgin and Status of the Arrhenius Equation. J. Chem. Educ. 1982, 59, 279. [CrossRef]

9. Ives, D.J.G. Chemical Thermodynamics: With Special Reference to Inorganic Chemistry; University Chemistry Series; Macdonald Technical and Scientific: Oxford, UK, 1971; ISBN 0-356-03736-3.

10. Boutilier, R.G. Mechanisms of Cell Survival in Hypoxia and Hypothermia. J. Exp. Biol. 2001, 204, 3171-3181.

11. Brewer, S.H.; Tang, Y.; Vu, D.M.; Gnanakaran, S.; Raleigh, D.P.; Dyer, R.B. Temperature Dependence of Water Interactions with the Amide Carbonyls of $\alpha$-Helices. Biochemistry 2012, 51, 5293-5299. [CrossRef] [PubMed]

12. Zandarashvili, L.; Iwahara, J. Temperature Dependence of Internal Motions of Protein Side-Chain NH3(+) Groups: Insight into Energy Barriers for Transient Breakage of Hydrogen Bonds. Biochemistry 2015, 54, 538-545. [CrossRef] [PubMed]

13. Hazel, J.R. Thermal Adaptation in Biological Membranes: Is Homeoviscous Adaptation the Explanation? Annu. Rev. Physiol. 1995, 57, 19-42. [CrossRef] [PubMed]

14. Smith, J.D.; Cappa, C.D.; Wilson, K.R.; Cohen, R.C.; Geissler, P.L.; Saykally, R.J. Unified Description of Temperature-Dependent Hydrogen-Bond Rearrangements in Liquid Water. Proc. Natl. Acad. Sci. USA 2005, 102, 14171-14174. [CrossRef]

15. Cordier, F.; Grzesiek, S. Temperature-Dependence of Protein Hydrogen Bond Properties as Studied by High-Resolution NMR. J. Mol. Biol. 2002, 317, 739-752. [CrossRef] [PubMed]

16. Dias, C.L.; Ala-Nissila, T.; Wong-ekkabut, J.; Vattulainen, I.; Grant, M.; Karttunen, M. The Hydrophobic Effect and Its Role in Cold Denaturation. Cryobiology 2010, 60, 91-99. [CrossRef]

17. Bon, D.; Chatauret, N.; Giraud, S.; Thuillier, R.; Favreau, F.; Hauet, T. New Strategies to Optimize Kidney Recovery and Preservation in Transplantation. Nat. Rev. Nephrol. 2012, 8, 339-347. [CrossRef] [PubMed]

18. Steichen, C.; Giraud, S.; Bon, D.; Barrou, B.; Badet, L.; Salamé, E.; Kerforne, T.; Allain, G.; Roumy, J.; Jayle, C.; et al. Barriers and Advances in Kidney Preservation. BioMed Res. Int. 2018, 2018, 9206257. [CrossRef] [PubMed]

19. Perkins, D.; Verma, M.; Park, K.J. Advances of Genomic Science and Systems Biology in Renal Transplantation: A Review. Semin. Immunopathol. 2011, 33, 211-218. [CrossRef] [PubMed]

20. Mast, F.D.; Ratushny, A.V.; Aitchison, J.D. Systems Cell Biology. J. Cell Biol. 2014, 206, 695-706. [CrossRef] [PubMed]

21. Tillet, S.; Giraud, S.; Delpech, P.O.; Thuillier, R.; Ameteau, V.; Goujon, J.M.; Renelier, B.; Macchi, L.; Hauet, T.; Mauco, G. Kidney Graft Outcome Using an Anti-Xa Therapeutic Strategy in an Experimental Model of Severe Ischaemia-Reperfusion Injury. Br. J. Surg. 2015, 102, 132-142. [CrossRef] [PubMed]

22. Thuillier, R.; Dutheil, D.; Trieu, M.T.N.; Mallet, V.; Allain, G.; Rousselot, M.; Denizot, M.; Goujon, J.-M.; Zal, F.; Hauet, T. Supplementation with a New Therapeutic Oxygen Carrier Reduces Chronic Fibrosis and Organ Dysfunction in Kidney Static Preservation. Am. J. Transplant. 2011, 11, 1845-1860. [CrossRef]

23. Bindea, G.; Mlecnik, B.; Hackl, H.; Charoentong, P.; Tosolini, M.; Kirilovsky, A.; Fridman, W.-H.; Pagès, F.; Trajanoski, Z.; Galon, J. ClueGO: A Cytoscape Plug-in to Decipher Functionally Grouped Gene Ontology and Pathway Annotation Networks. Bioinforma. Oxf. Engl. 2009, 25, 1091-1093. [CrossRef] [PubMed] 
24. Le Pape, S.; Pasini-Chabot, O.; Couturier, P.; Delpech, P.-O.; Volmer, R.; Quellard, N.; Ploeg, R.; Hauet, T.; Thuillier, R. Decoding Cold Ischaemia Time Impact on Kidney Graft: The Kinetics of the Unfolded Protein Response Pathways. Artif. Cells Nanomed. Biotechnol. 2018, 46, S873-S885. [CrossRef]

25. Debout, A.; Foucher, Y.; Trébern-Launay, K.; Legendre, C.; Kreis, H.; Mourad, G.; Garrigue, V.; Morelon, E.; Buron, F.; Rostaing, L.; et al. Each Additional Hour of Cold Ischemia Time Significantly Increases the Risk of Graft Failure and Mortality Following Renal Transplantation. Kidney Int. 2015, 87, 343-349. [CrossRef] [PubMed]

26. Castañón, M.J.; Walko, G.; Winter, L.; Wiche, G. Plectin-Intermediate Filament Partnership in Skin, Skeletal Muscle, and Peripheral Nerve. Histochem. Cell Biol. 2013, 140, 33-53. [CrossRef] [PubMed]

27. Bonventre, J.V.; Yang, L. Cellular Pathophysiology of Ischemic Acute Kidney Injury. J. Clin. Investig. 2011, 121, 4210-4221. [CrossRef]

28. Nowotny, M.; Bhattacharya, S.; Filipek, A.; Krezel, A.M.; Chazin, W.; Kuznicki, J. Characterization of the Interaction of Calcyclin (S100A6) and Calcyclin-Binding Protein. J. Biol. Chem. 2000, 275, 31178-31182. [CrossRef] [PubMed]

29. Donato, R.; Sorci, G.; Giambanco, I. S100A6 Protein: Functional Roles. Cell. Mol. Life Sci. CMLS 2017, 74, 2749-2760. [CrossRef]

30. Mofid, A.; Newman, N.S.; Lee, P.J.H.; Abbasi, C.; Matkar, P.N.; Rudenko, D.; Kuliszewski, M.A.; Chen, H.H.; Afrasiabi, K.; Tsoporis, J.N.; et al. Cardiac Overexpression of S100A6 Attenuates Cardiomyocyte Apoptosis and Reduces Infarct Size After Myocardial Ischemia-Reperfusion. J. Am. Heart Assoc. 2017, 6, e004738. [CrossRef]

31. Ul-Hussain, M.; Dermietzel, R.; Zoidl, G. Connexins and Cap-Independent Translation: Role of Internal Ribosome Entry Sites. Brain Res. 2012, 1487, 99-106. [CrossRef]

32. Barbosa, C.; Peixeiro, I.; Romão, L. Gene Expression Regulation by Upstream Open Reading Frames and Human Disease. PLoS Genet. 2013, 9, e1003529. [CrossRef] [PubMed]

33. Becker, M.; Gzyl, K.E.; Altamirano, A.M.; Vuong, A.; Urban, K.; Wieden, H.-J. The 70S Ribosome Modulates the ATPase Activity of Escherichia Coli YchF. RNA Biol. 2012, 9, 1288-1301. [CrossRef] [PubMed]

34. Guan, D.; Altan-Bonnet, N.; Parrott, A.M.; Arrigo, C.J.; Li, Q.; Khaleduzzaman, M.; Li, H.; Lee, C.-G.; Pe'ery, T.; Mathews, M.B. Nuclear Factor 45 (NF45) Is a Regulatory Subunit of Complexes with NF90/110 Involved in Mitotic Control. Mol. Cell. Biol. 2008, 28, 4629-4641. [CrossRef]

35. Barber, G.N. The NFAR's (Nuclear Factors Associated with DsRNA): Evolutionarily Conserved Members of the DsRNA Binding Protein Family. RNA Biol. 2009, 6, 35-39. [CrossRef]

36. Dutertre, M.; Sanchez, G.; Barbier, J.; Corcos, L.; Auboeuf, D. The Emerging Role of Pre-Messenger RNA Splicing in Stress Responses: Sending Alternative Messages and Silent Messengers. RNA Biol. 2011, 8, 740-747. [CrossRef] [PubMed]

37. Corbi, N.; Batassa, E.M.; Pisani, C.; Onori, A.; Di Certo, M.G.; Strimpakos, G.; Fanciulli, M.; Mattei, E.; Passananti, C. The EEF1 $\gamma$ Subunit Contacts RNA Polymerase II and Binds Vimentin Promoter Region. PLoS ONE 2010, 5, e14481. [CrossRef]

38. Koonin, E.V.; Mushegian, A.R.; Tatusov, R.L.; Altschul, S.F.; Bryant, S.H.; Bork, P.; Valencia, A. Eukaryotic Translation Elongation Factor 1 Gamma Contains a Glutathione Transferase Domain-Study of a Diverse, Ancient Protein Superfamily Using Motif Search and Structural Modeling. Protein Sci. Publ. Protein Soc. 1994, 3, 2045-2054. [CrossRef] [PubMed]

39. Celeste, A.; Fernandez-Capetillo, O.; Kruhlak, M.J.; Pilch, D.R.; Staudt, D.W.; Lee, A.; Bonner, R.F.; Bonner, W.M.; Nussenzweig, A. Histone H2AX Phosphorylation Is Dispensable for the Initial Recognition of DNA Breaks. Nat. Cell Biol. 2003, 5, 675-679. [CrossRef]

40. Economopoulou, M.; Langer, H.F.; Celeste, A.; Orlova, V.V.; Choi, E.Y.; Ma, M.; Vassilopoulos, A.; Callen, E.; Deng, C.; Bassing, C.H.; et al. Histone H2AX Is Integral to Hypoxia-Driven Neovascularization. Nat. Med. 2009, 15, 553-558. [CrossRef] [PubMed]

41. Boros, L.G.; Puigjaner, J.; Cascante, M.; Lee, W.N.; Brandes, J.L.; Bassilian, S.; Yusuf, F.I.; Williams, R.D.; Muscarella, P.; Melvin, W.S.; et al. Oxythiamine and Dehydroepiandrosterone Inhibit the Nonoxidative Synthesis of Ribose and Tumor Cell Proliferation. Cancer Res. 1997, 57, 4242-4248.

42. Xu, I.M.-J.; Lai, R.K.-H.; Lin, S.-H.; Tse, A.P.-W.; Chiu, D.K.-C.; Koh, H.-Y.; Law, C.-T.; Wong, C.-M.; Cai, Z.; Wong, C.C.-L.; et al. Transketolase Counteracts Oxidative Stress to Drive Cancer Development. Proc. Natl. Acad. Sci. USA 2016, 113, E725-E734. [CrossRef]

43. Salamon, C.; Chervenak, M.; Piatigorsky, J.; Sax, C.M. The Mouse Transketolase (TKT) Gene: Cloning, Characterization, and Functional Promoter Analysis. Genomics 1998, 48, 209-220. [CrossRef]

44. Stenmark, H.; Olkkonen, V.M. The Rab GTPase Family. Genome Biol. 2001, 2, REVIEWS3007. [CrossRef]

45. Kane, S.; Sano, H.; Liu, S.C.H.; Asara, J.M.; Lane, W.S.; Garner, C.C.; Lienhard, G.E. A Method to Identify Serine Kinase Substrates. Akt Phosphorylates a Novel Adipocyte Protein with a Rab GTPase-Activating Protein (GAP) Domain. J. Biol. Chem. 2002, 277, 22115-22118. [CrossRef] [PubMed]

46. Di Chiara, M.; Glaudemans, B.; Loffing-Cueni, D.; Odermatt, A.; Al-Hasani, H.; Devuyst, O.; Faresse, N.; Loffing, J. Rab-GAP TBC1D4 (AS160) Is Dispensable for the Renal Control of Sodium and Water Homeostasis but Regulates GLUT4 in Mouse Kidney. Am. J. Physiol. Renal Physiol. 2015, 309, F779-F790. [CrossRef]

47. Alves, D.S.; Farr, G.A.; Seo-Mayer, P.; Caplan, M.J. AS160 Associates with the Na+,K+-ATPase and Mediates the Adenosine Monophosphate-Stimulated Protein Kinase-Dependent Regulation of Sodium Pump Surface Expression. Mol. Biol. Cell 2010, 21, 4400-4408. [CrossRef]

48. Sun, Y.; Jin, P.; Witte, D.P.; Grabowski, G.A. Prosaposin: Promoter Analysis and Central-Nervous-System-Preferential Elements for Expression in Vivo. Biochem. J. 2000, 352 Pt 2, 549-556. [CrossRef] 
49. Ochiai, T.; Takenaka, Y.; Kuramoto, Y.; Kasuya, M.; Fukuda, K.; Kimura, M.; Shimeno, H.; Misasi, R.; Hiraiwa, M.; Soeda, S. Molecular Mechanism for Neuro-Protective Effect of Prosaposin against Oxidative Stress: Its Regulation of Dimeric Transcription Factor Formation. Biochim. Biophys. Acta 2008, 1780, 1441-1447. [CrossRef] [PubMed]

50. Benaud, C.; Gentil, B.J.; Assard, N.; Court, M.; Garin, J.; Delphin, C.; Baudier, J. AHNAK Interaction with the Annexin 2/S100A10 Complex Regulates Cell Membrane Cytoarchitecture. J. Cell Biol. 2004, 164, 133-144. [CrossRef] [PubMed]

51. Borgonovo, B.; Cocucci, E.; Racchetti, G.; Podini, P.; Bachi, A.; Meldolesi, J. Regulated Exocytosis: A Novel, Widely Expressed System. Nat. Cell Biol. 2002, 4, 955-962. [CrossRef] [PubMed]

52. Enrich, C.; Rentero, C.; de Muga, S.V.; Reverter, M.; Mulay, V.; Wood, P.; Koese, M.; Grewal, T. Annexin A6-Linking Ca(2+) Signaling with Cholesterol Transport. Biochim. Biophys. Acta 2011, 1813, 935-947. [CrossRef] [PubMed]

53. Monastyrskaya, K.; Tschumi, F.; Babiychuk, E.B.; Stroka, D.; Draeger, A. Annexins Sense Changes in Intracellular PH during Hypoxia. Biochem. J. 2008, 409, 65-75. [CrossRef]

54. Giraud, S.; Steichen, C.; Allain, G.; Couturier, P.; Labourdette, D.; Lamarre, S.; Ameteau, V.; Tillet, S.; Hannaert, P.; Thuillier, R.; et al. Dynamic Transcriptomic Analysis of Ischemic Injury in a Porcine Pre-Clinical Model Mimicking Donors Deceased after Circulatory Death. Sci. Rep. 2018, 8, 5986. [CrossRef]

55. Giraud, S.; Thuillier, R.; Cau, J.; Hauet, T. In Vitro/Ex Vivo Models for the Study of Ischemia Reperfusion Injury during Kidney Perfusion. Int. J. Mol. Sci. 2020, 21, 8156. [CrossRef]

56. Hosgood, S.A.; Hoff, M.; Nicholson, M.L. Treatment of Transplant Kidneys during Machine Perfusion. Transpl. Int. Off. J. Eur. Soc. Organ Transplant. 2020, 34, 224-232. [CrossRef] [PubMed]

57. Steichen, C.; Giraud, S.; Hauet, T. Combining Kidney Organoids and Genome Editing Technologies for a Better Understanding of Physiopathological Mechanisms of Renal Diseases: State of the Art. Front. Med. 2020, 7, 10. [CrossRef] [PubMed]

58. Melis, N.; Thuillier, R.; Steichen, C.; Giraud, S.; Sauvageon, Y.; Kaminski, J.; Pelé, T.; Badet, L.; Richer, J.P.; Barrera-Chimal, J.; et al. Emerging Therapeutic Strategies for Transplantation-Induced Acute Kidney Injury: Protecting the Organelles and the Vascular Bed. Expert Opin. Ther. Targets 2019, 23, 495-509. [CrossRef] [PubMed]

59. Hauet, T.; Thuillier, R. Protecting the Mitochondria Against Ischemia Reperfusion: A Gassy Solution? Am. J. Transplant. 2017, 17, 313-314. [CrossRef]

60. Thuillier, R.; Hauet, T. Impact of Hypothermia and Oxygen Deprivation on the Cytoskeleton in Organ Preservation Models. BioMed Res. Int. 2018, 2018, 8926724. [CrossRef] [PubMed]

61. Nieuwenhuijs-Moeke, G.J.; Pischke, S.E.; Berger, S.P.; Sanders, J.S.F.; Pol, R.A.; Struys, M.M.R.F.; Ploeg, R.J.; Leuvenink, H.G.D. Ischemia and Reperfusion Injury in Kidney Transplantation: Relevant Mechanisms in Injury and Repair. J. Clin. Med. 2020, 9, 253. [CrossRef]

62. Chen, W.; Lv, L.; Nong, Z.; Chen, X.; Pan, X.; Chen, C. Hyperbaric Oxygen Protects against Myocardial Ischemia-reperfusion Injury through Inhibiting Mitochondria Dysfunction and Autophagy. Mol. Med. Rep. 2020, 22, 4254-4264. [CrossRef] [PubMed]

63. Wang, P.; Guan, Y.-F.; Du, H.; Zhai, Q.-W.; Su, D.-F.; Miao, C.-Y. Induction of Autophagy Contributes to the Neuroprotection of Nicotinamide Phosphoribosyltransferase in Cerebral Ischemia. Autophagy 2012, 8, 77-87. [CrossRef] [PubMed]

64. Zhu, J.; Wang, Y.-F.; Chai, X.-M.; Qian, K.; Zhang, L.-W.; Peng, P.; Chen, P.-M.; Cao, J.-F.; Qin, Z.-H.; Sheng, R.; et al. Exogenous NADPH Ameliorates Myocardial Ischemia-Reperfusion Injury in Rats through Activating AMPK/MTOR Pathway. Acta Pharmacol. Sin. 2020, 41, 535-545. [CrossRef] [PubMed]

65. Li, Q.; Gulati, A.; Lemaire, M.; Nottoli, T.; Bale, A.; Tufro, A. Rho-GTPase Activating Protein Myosin MYO9A Identified as a Novel Candidate Gene for Monogenic Focal Segmental Glomerulosclerosis. Kidney Int. 2021, in press. [CrossRef] [PubMed]

66. Vandesompele, J.; De Preter, K.; Pattyn, F.; Poppe, B.; Van Roy, N.; De Paepe, A.; Speleman, F. Accurate Normalization of Real-Time Quantitative RT-PCR Data by Geometric Averaging of Multiple Internal Control Genes. Genome Biol. 2002, 3, research0034.1. [CrossRef] [PubMed] 